\title{
Human Resource Disclosures in UK Corporate Annual Reports: To What Extent Do These Reflect Organisational Priorities Towards Labour?
}

\author{
K. Vithana ${ }^{1}$ (D) T. Soobaroyen ${ }^{2} \cdot$ C. G. Ntim ${ }^{1}$
}

Received: 9 June 2018 / Accepted: 16 September 2019 / Published online: 28 September 2019

(c) The Author(s) 2019

\begin{abstract}
Our study analyses the nature, quality and extent of human resource disclosures (HRDs) of UK Financial Times Stock Exchange (FTSE) 100 firms by relying on a novel disclosure index measuring the depth and breadth of disclosures. Contextually, we focus on the 5-year period following the then Labour government's attempts to encourage firms to formally report on their human resource management practices and to foster deeper employer-employee engagement. First, we evaluate the degree to which companies report comprehensively (or substantively) on a number of HRD items that we classify as "procedural" or "sustainable." Second, we hypothesise that a company's employee relation ideology (using a proxy to measure a company's level of "unitarism") is positively associated with HRD. Our results indicate that: (i) whilst there has been an increase in the breadth of HRD in terms of procedural and sustainable items being disclosed, the evolution towards a more comprehensive and in-depth form of HRD remains rather limited; and (ii) there is a positive association between a company's employee relation ideology (unitarism) and the level of HRD. Theoretically, we conceive of HRD both as a reflection of an organisation's orientation towards a key stakeholder (unitarist relations with labour) and a legitimacy seeking exercise at a time of changing societal conditions. We contribute to the scant literature on the extent and determinants of HRD since prior research tends to subsume employee-related disclosures within the broader concept of social, ethical or intellectual capital disclosures. We also propose a disclosure checklist to underpin future HRD research.
\end{abstract}

Keywords Human resource disclosure $\cdot$ Employee relation ideology $\cdot$ Stakeholder theory $\cdot$ Legitimacy theory

\section{Introduction}

Whether from an economic, ethical or corporate social responsibility perspective, there have been recurring concerns amongst government, accounting and human resource professional bodies, investors, civil society organisations, and academics on the extent to which (if at all) the contribution of employees is recognised in corporate accounting

K. Vithana

v.k.vithana@soton.ac.uk

T. Soobaroyen

tsooba@essex.ac.uk

C. G. Ntim

C.G.Ntim@soton.ac.uk

1 Southampton Business School, University of Southampton, Highfield, Southampton SO17 1BJ, UK

2 Essex Accounting Centre, Essex Business School, University of Essex, Colchester Campus, Wivenhoe Park, Colchester CO4 3SQ, UK and disclosure models (Roslender et al. 2004; Ejiogu and Ejiogu 2018; Bowrin 2018). In particular, the inability of mandatory accounting and financial reporting practice to address this gap has been viewed as a marginalisation of the firms' employee intellectual base, and the domination of capital over labour interests (Bowrin, 2018; Roslender and Stevenson 2009; Roslender et al. 2015). Instead, some firms appear to have resorted to the use of voluntary and narrative disclosure of employee information, albeit the evidence is often subsumed within broader explorations of ethical, intellectual capital (IC), and social disclosures (Abeysekera and Guthrie 2004, 2005; Lin et al. 2012; Samudhram et al. 2014). The emphasis has mostly been on measuring HRD items from a dichotomous perspective (presence/absence) or volumetric perspective (e.g. number of words and sentences), and reliance on checklists pertaining to broader conceptual frameworks (e.g. intellectual capital; social; ethical), which do not enable a richer appreciation of HRD information. Finally, there remains a limited understanding of the theoretical motivations and firm-level determinants of 
human resource disclosure (HRD), taking into consideration the prevailing historical, social, and political context during which disclosures are made.

Our specific interest lies in the UK Labour government's attempt to formalise corporate HRD practice in the mid2000s (Department of Trade and Industry DTI 2003a, b) with the Accounting for People project; which was billed as a significant historical call for action (Roslender and Stevenson 2009; Roslender et al. 2015, Bowrin 2018). Although there was much debate over several years in relation to this ultimately unsuccessful policy intervention (Stittle 2004; Roslender and Stevenson 2009), there has not been any empirical study of how UK companies responded to the prevailing social realities brought about by the government at the time. Furthermore, we contend that there has been little attempt to examine whether a firm's own "mindset" in relation to employee relations (Brown 2000; Mäkelä 2013) might influence the level of HRD. Specifically, we propose that employee relation ideology (i.e. unitarism vs. non-unitarism-pluralism/radicalism) could be a helpful notion to appreciate which firms might be more attuned to labour/ employee interests and by extension, be more amenable to engage in comprehensive forms of HRD. Consequently, we formulate the following research questions: (i) what has been UK firms' disposition towards comprehensive forms of HRD following the 2003 Labour government's attempts to foster more corporate accountability? and (ii) to what extent does the firm's employee relation ideology influence the nature and comprehensiveness of HRD in the presence of other firm-specific and corporate governance characteristics?

Our research questions are motivated by two contemporary developments. First, there have been recent calls for evidence on HRD from professional bodies, such as the UK Chartered Institute of Personnel Development (CIPD). Their calls have also arisen out of the need to explore issues, including how to "count the uncountables" (i.e. people) (Hesketh 2013) and how the visibility of human "capital" can be improved and better reported in annual reports (CIPD 2015). An understanding of how and why disclosures evolved or not under previous calls for reform would provide a useful reference point for any more recent empirical explorations. Relatedly, Bowrin (2018) recently examines the case of HRDs, but these largely focus on cross-country, rather than firm-level, determinants (e.g. national governance and foreign influence) for companies operating in several African and Caribbean countries.

Secondly, and as highlighted previously, a few studies (e.g. Abeysekera and Guthrie 2004, 2005; Abeysekera 2008; Bowrin 2018) have examined some facets of HRDs, but these are often subsumed within broader (and arguably more shareholder wealth-centric) concepts, such as IC reporting (Abeysekera and Guthrie 2004; Abhayawansa and Abeysekera 2008). Furthermore, social and/or environmental studies have begun to focus on the "comprehensiveness" or "substantiveness" of the information (e.g. Bouten et al. 2011; Soobaroyen and Ntim 2013); which can enable economic and social stakeholders to make a more informed judgement of a company's aims/commitment, activities, and performance in relation to a particular theme (Sepasi et al. 2018). All too often, however, disclosure can be perfunctory and selective in nature, raising not only ethical concerns as to the intentions of the organisation in its communication with stakeholders, but also functional limitations in terms of the information's usefulness. Hence, an empirical research design to investigate HRD should consider how comprehensive and substantive HRDs actually are.

We adopt a relatively novel approach to measure the depth and breadth of disclosure, and hence the comprehensiveness, of HRD. The disclosure index also ascertains HRDs over two dimensions; namely, (a) the theme of HRD (informed by previous empirical studies) (Abeysekera 2008; Ax and Marton 2008; Subbarao and Zeghal 1997), and (b) the level of comprehensiveness in the disclosure measured as (i) objectives, (ii) measurements, (iii) targets, (iv) initiatives, and (v) achievements. This approach expands Bouten et al.'s (2011) work on a comprehensive reporting model, which has three information types per theme, namely, "vision and goals," "management approach", and "performance indicator." Finally, we classify 22 HRD items into two categories: those that can be seen as a reflection of (i) sustainable (longterm) HR-related investment, or (ii) procedural (short-term or more routine) aspects of HR practice.

Theoretically, our study firstly draws on the stakeholder and legitimacy perspectives to frame why large corporations voluntarily disclose information relating to their employees (Chen and Roberts 2010; Su 2014). Whilst these theories are often seen as distinct in relation to their different disciplinary origins, they collectively provide an understanding of the diverse role of communication and disclosure in the interactions between the organisation and its environment, whether "environment" refers to particular interest groups (e.g. employees) or more broadly to "society," in terms of the norms, expectations and values that it reflects (Mahadeo et al. 2011; Soobaroyen and Ntim 2013). Furthermore, given the specificity of the stakeholders in our study, we provide a further grounding of this theoretical framework by drawing from the concept of stakeholder salience (Mitchell et al. 1997) and employee relation ideologies (Brown 2000) to argue that an organisational/managerial intention towards developing a common and mutual objective with employees/ labour is consistent with a unitarist ideology, which in turn will be associated to more comprehensive forms of HRD. Moreover, we bring forward the concept of moral legitimacy (Suchman 1995; Mahadeo et al. 2011) to conceptualise changes in organisational disclosures in response to societal (including political) attitudes about the need for more 
corporate accountability towards labour interests. Hence, distinct from previous studies, the theoretical framework that we employ seeks to analyse the nature (themes and categorisations) of HRD information, its comprehensiveness over the period of analysis in response to societal changes and the association between HRD and the extent of the company's perceived affiliation to unitarist (non-unitarist) principles.

The paper contributes to the literature in the following ways. First, it provides contextually-informed longitudinal evidence of HRD practices; and in particular reveals that there is a significant improvement in HRD over the study period, especially in terms of sustainable HRD, such as employee involvement and training. Results further reveal that procedural HRD items are generally disclosed at the symbolic level, and that there is a positive association between a unitarist employee relation ideology and corporate HRD. Secondly, and inspired by prior work considering the comprehensiveness of social and environmental disclosure (e.g. Bouten et al., 2011) and the substantive and symbolic characterisation of disclosure (Day and Woodward 2004; Soobaroyen and Ntim 2013; Michelon et al. 2015), our disclosure index provides a comprehensive methodological tool to assess HRD practice. In particular, it is sufficiently detailed and distinct from the mainstream notion of IC to be more appropriate to assess a firm's disposition towards HRD. Furthermore, as opposed to previous studies (McCracken et al. 2018), our approach to capture the depth of reporting extends the currently available tools and helps the reader to assess the substantive/comprehensive or selective/symbolic nature of HRD. Finally, our study draws from Brown's work (2000) to propose a firm-level variable- the extent of the organisation's unitarist orientation-as a proxy for a company's employee relation ideology.

The remainder of the paper is organised as follows. section "HRD: Previous Research, Theory and Hypotheses" reviews the extant HR disclosure literature and the UK setting leading to the theoretical underpinning and hypotheses development, while section "Data and methods" sets out the methodology. The analysis and findings are reported in section Data analysis and results. The discussion is presented in section "Discussion", followed by the conclusion in section "Conclusion", including the ethical implications of organisational disclosure.

\section{HRD: Previous Research, Theory and Hypotheses}

The research agenda on IC disclosure has generated a notable body of work on the extent of disclosures or narratives incorporating various aspects of "human capital" (HC) in a number of contexts, mainly on the grounds that such information is market-sensitive (Abhayawansa and Abeysekera 2008; Cuganesan
2006; Lin et al. 2012; Samagaio and Rodrigues 2016). Nevertheless, the extent of IC disclosure has been found to be generally low or fluctuating considerably; with some attention paid to HC reporting more recently (McCracken et al. 2018) that is suggestive of stakeholder-led motivations rather than marketled ones. Yet, contextual analyses of HRD remain few and far between, and there has been little emphasis on organisationlevel variables that may explain decisions to engage in more comprehensive or selective forms of disclosure.

Methodologically, many of the above-mentioned studies rely on dichotomous approaches to measure corporate disclosures (Barako et al. 2006; Roberts 1992), and arguably, this approach does not capture how comprehensive the disclosed information is (Roslender and Dyson 1992; Wintermantel and Mattimore 1997). For example, McCracken et al. (2018) recently conducted a study of the UK FTSE 100 companies and found a resurgence of interest in HRD. However, the conclusions are based on a volumetric disclosure analysis (sentence counts). Furthermore, whilst their findings revealed that the HRD practice has increased over the period of analysis, the authors offered limited theoretical explanation and arguments for the observable improvement in practice. Moreover, very little has emerged to-date in terms of detailed cross-sectional and longitudinal evidence (McCracken et al. 2018; Roslender and Stevenson 2009; Roslender et al. 2004, 2015).

Overall therefore, the empirical work on HRD can be profiled as: (i) largely descriptive accounts of disclosures (e.g. Abeysekera 2008) with limited theoretical underpinnings; (ii) explanatory studies limited to general firm-level determinants (e.g. firm size and industry); and (iii) theoretically informed studies with broader set of explanatory variables, such as governance and culture (e.g. Li et al. 2008, 2012; Bowrin 2018). In this third category of studies, however, there has been an emphasis on IC disclosures rather than on HRD per se. Hence, the above-mentioned gaps provide the motivation for our study.

\section{HRD Frameworks and Reforms in the UK Corporate Setting}

There have been several exhortations to improve the practice of accounting for HR since its formal inception in the UK in the 1970s (AAA 1973; Day and Woodward 2004; McCracken et al. 2018). Some of these initiatives influenced regulatory frameworks and legislation (i.e. Companies Act 1985; Employment Act 1982; Employment Protection Act 1975; Companies Act 2006). Following the election of a Labour government in 1997, policy initiatives relating to $\mathrm{HC}$ management practices resurfaced in the early and mid2000s (DTI 2003a, b) and fostered a lively debate. Among these, the Accounting for People initiative introduced by the UK government in January 2003 was seen to be a concerted 
effort to formalise a corporate practice of accounting for HR, thus recognising labour as a key stakeholder.

In January 2003, the UK government announced a taskforce on $\mathrm{HC}$ management, which completed the Accounting for People report in November of the same year. In particular, the report highlighted the possibility of accounting for people by UK firms, particularly for large quoted public firms (DTI 2003a, b). Initiatives to account for people took place in parallel with efforts to mandate the Operational and Financial Review (OFR) for UK listed firms; it was proposed that the OFR would be taken as the platform to account for HR as well. In January 2005, draft legislation on reforming company reporting of employees went to Parliament, and was legally enacted in March 2005. According to the legislation, the provision of HR information as a part of the OFR became a statutory requirement for large UK-quoted companies with the financial year commencing April 1, 2005. Surprisingly, by November 2005, the requirement to compile an OFR (inclusive of the legal obligation for UK firms to disclose information relating to their employees) was abandoned. The UK accounting profession was seen to have effectively lobbied against the proposed initiatives, leading to academic criticisms (Roslender and Stevenson 2009; Roslender et al. 2004, 2015), and impacting changes in corporate HRD practice over time. A corporate reluctance to engage with employee-related disclosures has been previously noted. For example, Day and Woodward (2004) revealed that firms disregarded even the statutory minimum disclosure requirements. Interestingly, the legal sanctions, which would have been applicable for such non-compliance, did not appear to be enforced, possibly indicating a lack of interest from firms, enforcement agencies, and/or limited market-led monitoring mechanisms. In conclusion, there has been little in the way of empirical analysis to study HRD following such key events. We now consider the theoretical framing of our study.

\section{HRD, Stakeholder Salience and the Pursuit of Moral Legitimacy}

Firstly, stakeholder theory underlines the role of internal and external actors and the influence these actors may have on firms as a result of their financial or non-financial interest(s) (Donaldson and Preston 1995; Jensen 2002). In this regard, stakeholder theory has been relied upon to explain the reporting of social practices reflecting the informational needs of multiple stakeholder groups (Bouten et al. 2011; Pedrini 2007; Roberts 1992). Faced with demands for accountability in relation to these interests, the ethical variant of stakeholder theory suggests that organisations need to unilaterally address these demands, however multiple they might be, and are expected to adopt comprehensive, substantive HRD practices to reflect these accountability relationships. A different, and arguably more common, perspective is the instrumental variant of stakeholder theory, whereby a firm seeks to manage and placate stakeholder concerns by relying on a blend of substantive and symbolic information-in effect a more strategic approach in the mapping of the relationship between organisation and stakeholders (Soobaroyen and Ntim 2013). The power, legitimacy, and urgency characteristics of the target stakeholders guide disclosure priorities in order to ensure a strategic form of stakeholder management (Clement 2005; Mitchell et al. 1997). For example, Mitchell et al. (1997) argue that stakeholders that are more legitimate and powerful and have urgent concerns will require more corporate attention and disclosure. Hence, from an instrumental perspective, stakeholder theory underpins a need to prioritise communication to target the specific audiences that are more likely to impact a firm's ability to maintain and sustain its activities. As previously argued by Soobaroyen and Ntim (2013), a strategic approach to organisational disclosure can involve a combination of substantive and symbolic information, since even symbolic displays of commitment may be sufficient to manage stakeholder interests in given contexts and circumstances. At the same time, a perceived or actual change in stakeholder salience may lead to a variation in the nature of the disclosures. Specifically, the decision by the UK government to endorse and foster the Accounting for People project can be seen as a change in the salience of a given stakeholder (labour/ employees), and can bring out a corporate response.

Therefore, it may be argued that organisations may substantively engage in practices and initiatives to bring about genuine change in employee/labour conditions (sustainable HR) together with meeting HR procedures and processes (procedural HR), as is reflected in a comprehensive or substantive form of HRD. Alternatively, organisations may partially adopt practices and/or emphasise procedural matters without bringing about any meaningful change. A selective form of HRD may thus be observed, which would reflect a symbolic acknowledgement of employee/labour interests.

Secondly, in line with the legitimacy argument (Chen and Roberts 2010), firms voluntarily disclose or withhold information because they assume such communication is relevant and important to legitimise their actions and dispositions towards societal norms and values. Thus, firms seek to legitimise their continued survival by taking desired actions or by appearing to take desired actions (Abeysekera and Guthrie 2005; Ehnert et al. 2016). In so doing, the communication of an affinity with, and/or adherence to, the expectations of wider society in terms of how employees should be treated by their employers reflects an organisational aspiration to be doing the "right thing." Suchman (1995, p. 578) refers to this as the pursuit of "moral legitimacy" whereby the emphasis is not on whether a given practice (HRD) will benefit a given 
external evaluator (employee/labour), but whether the activity is seen to be appropriate to promote societal welfare (Mahadeo et al. 2011).

In this respect, and informed by Suchman (1995), moral legitimacy can be evaluated from two perspectives: "consequential" (e.g. disclosures may refer to social outcomes) and "processual" (e.g. disclosures outline use of procedures). Within the moral legitimacy perspective, disclosures could be of any form or content (whether comprehensive or selective) since even symbolic displays of commitment may be sufficient to secure legitimacy. Soobaroyen and Ntim (2013) contend that more detailed forms of reporting may be required if a particular issue involving the organisation has become pressing from a societal perspective (e.g. rights of employees, tax evasion).

Finally, one needs to consider that societal expectations are automatically sympathetic to labour priorities; for example, the US context privileges flexibility in labour relations, which offers firms in the US the ability to hire and fire with minimum regulatory oversight. Contrastingly, the decision of the then Labour-led UK government to endorse an Accounting for People report suggests a change of political view and policy, which could also be seen as a change in societal expectations to which organisations respond through the communication of HRD.

Considering the depth of disclosure in the annual reports, HRD may vary from the selection of information presented symbolically to convey an impression, to a very comprehensive analysis of information. In terms of the breadth of HRD items contained in our disclosure index, we therefore consider a continuum along which some items are inherently more related to long-term/sustainable HR investment, while others are naturally more procedural in orientation, focusing on HR practices, processes and systems. The breadth and depth of the categories are illustrated in Figs. 1 and 2.

Relying on the stakeholder and the legitimacy arguments, and on the context underlying the UK debate over the recognition of the role and contribution of labour/employees during the mid-2000s, we argue that UK firms will be expected to engage in more comprehensive and substantive forms of disclosure following the attempted reforms. This leads us to the first hypothesis:

H1 HRDs are more likely to be increasingly substantive and comprehensive from 2005 to 2009.

\section{Organisational Ideologies of Employee Relations as a Determinant of HRDs}

Whilst the stakeholder and legitimacy framework outlined above can contribute to an explanation of trends in the different types of HRD over time in a given context, they are somewhat limited in terms of explaining variations between companies within the same context. In this respect, the literature already provides for a number of mainstream firmlevel variables (e.g. size, industry and governance structure), which seek to reflect general managerial intentions or orientations towards a given social practice or behaviour (Barako et al. 2006; Abeysekera 2010). For example, the presence and/or prevalence of independent directors on the board has been associated to a greater extent of social responsibility disclosures, due to the influence they may have on the organisation's strategy and approach towards social stakeholders (Barako et al. 2006), and, hence in terms of their ability to influence managerial intentions. In our case however, we extend this consideration of managerial orientations towards
Fig. 1 The interpretive framework: comprehensiveness of the disclosures

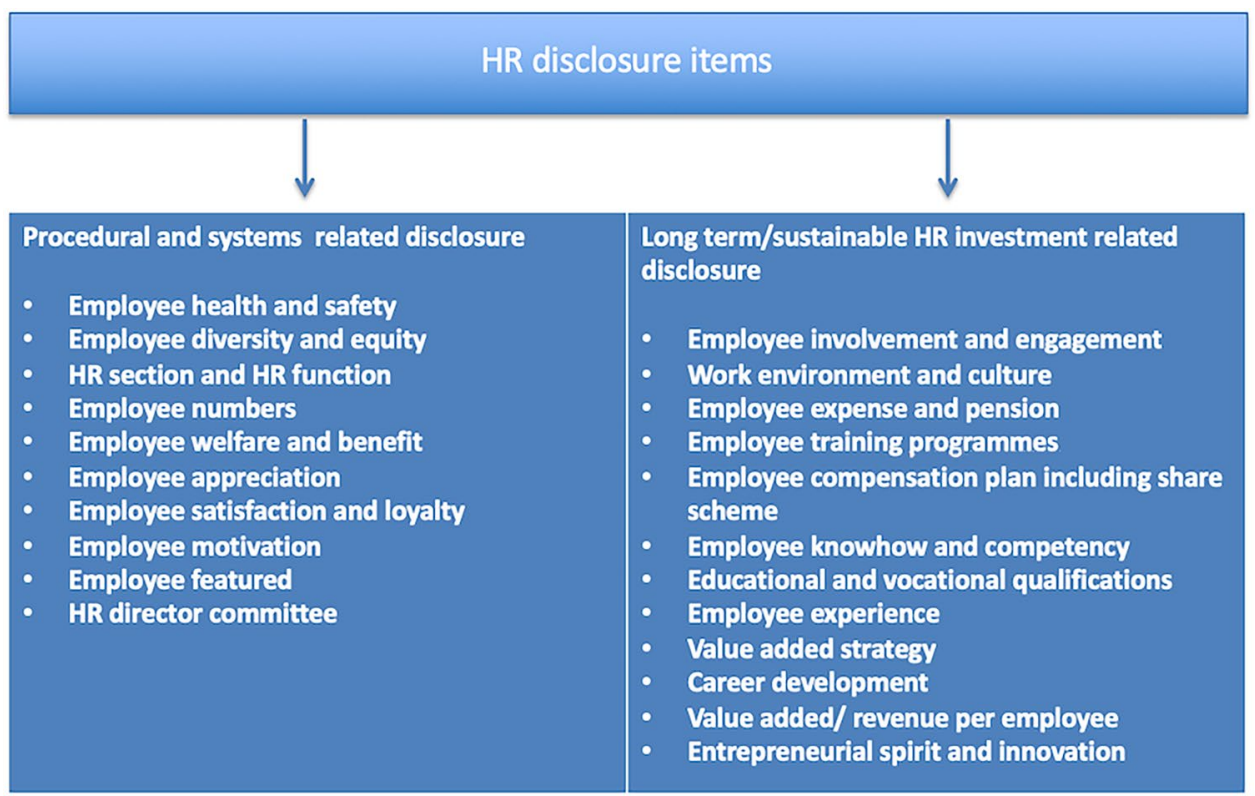


Fig. 2 The interpretive framework: depth of the disclosures

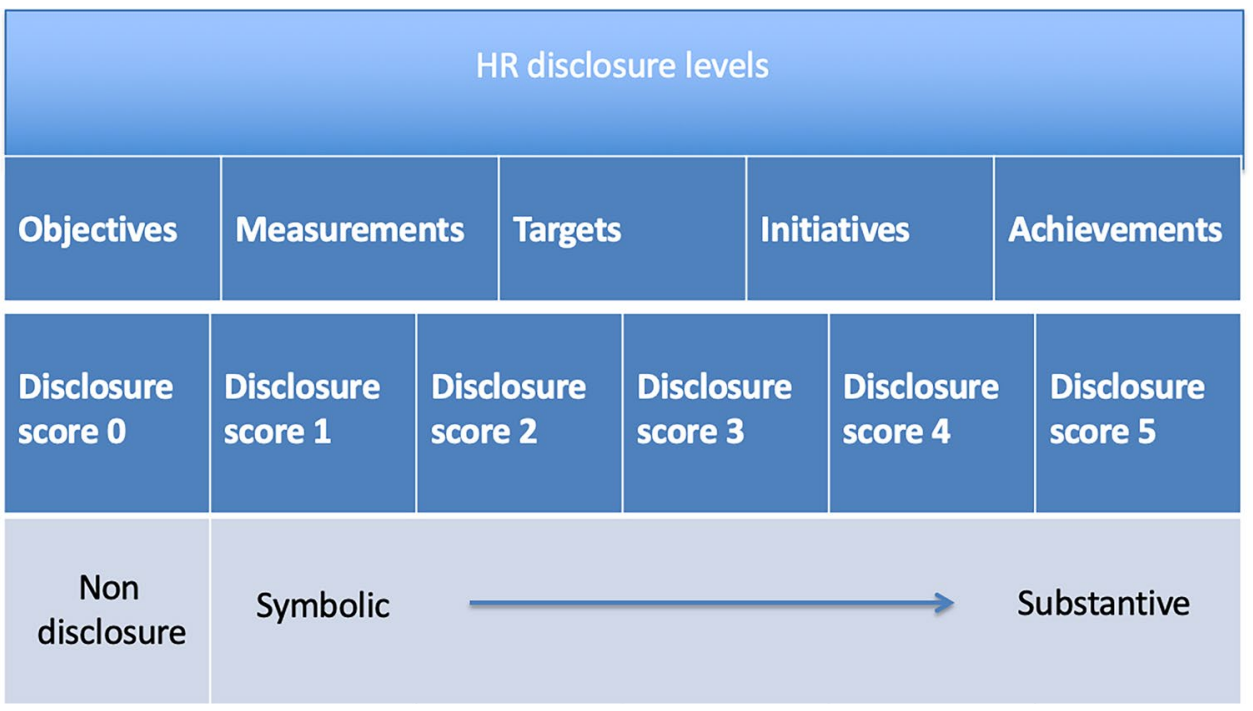

labour by drawing upon Brown's (2000) work on the typology of employee relations ideologies: namely "unitarist," "pluralist," and "radical" forms. An understanding of using these ideologies to explain how/why certain information and disclosures are communicated to different stakeholders has only recently emerged in the literature (Mäkelä 2013).

Firstly, within a "unitarist" ideological environment, employees/labour and management/owners tends to have common and mutual objectives that are subsequently pursued in a friendly and supportive environment for $\mathrm{HC}$ management and disclosure (Brown 2000). In this scenario, HRD tends to take a more comprehensive or substantive form, and in recognition of the ethical variant of stakeholder theory, communication is viewed as a means to improve work relations by "... reducing conflict, overcoming suspicion and promoting greater harmony in the workplace" (Smith 1985, p. 1).

By contrast, in a "non-unitarist" (pluralist/radical) ideological environment, the relationships between labour, management, and to some extent, capital providers, with regards to the central objectives of a firm, tend to be antagonistic and confrontational as a result of divergences in their expectations relating to HR investments, management, and disclosure. According to Brown (2000, p. 51), such conflict is based on genuinely different interests. Disclosure becomes part of a conflictual accountability process between the firm and its staff, and underpins negotiations between the parties. In this case, and confronted with these pressures, we argue that HRDs are likely to be more selective in orientation, and symbolic at times (Ashforth and Gibbs 1990), reflecting the degree of conflict amongst the key corporate actors. At the other end of the spectrum, the radical perspective draws on the MarXist argument of labour exploitation and why/how companies extract the surplus value from labour to generate more profit; employers are more powerful and have more authority over employees. In this context, corporate disclosure is reflective of a capitalist logic and employee representatives are inherently suspicious of engaging with the assumptions, language and discourses underlying HRD.

In a corporate context where a unitarist ideology underpins a firm's managerial intentions, we argue that the firm provides a more explicit position on industrial relation practices, including union activities. In contrast, an inherent antagonistic relationship in a non-unitarist environment implies that disclosures relating to industrial relations and union activities are less likely to be comprehensive and consistent in terms of their information content, reflecting apparent divergences from the expectations of the key stakeholders. Since pluralist/radicalist ideologies are associated with a state of disagreement between employee unions/labour and management/owners, we classify these concepts as a non-unitarist (i.e. pluralist/radicalist) ideology of employee relations. Therefore, we contend that a disclosure with a comprehensive coverage of HRD information would be consistent with a unitarist employee relation ideology. In contrast, a non-unitarist (pluralist/radicalist) employee relation ideology will be associated with a more selective and symbolic form of reporting. This leads to the second research hypothesis:

H2 The more unitarist the company's employee relation ideology is, the more comprehensive (or substantive) the HRDs are likely to be.

\section{Data and Methods}

\section{Research Strategy, Data and Sampling}

Content analysis has been a very common strategy in codifying and analysing voluntary disclosure practices in firms' 
annual reports, such as accounting for IC (Li et al. 2008), corporate governance (Armstrong et al. 2010; Barako et al. 2006), HRD (Beattie and Smith 2010; Cormier et al. 2009), and corporate social responsibility (Bouten et al. 2011; Roberts 1992; Vuontisjärvi 2006). We adopt a similar strategy for our study of HRD practices by UK FTSE100 firms.

In order to identify if/how a firms' disposition towards HRD changed following the UK government's attempts to encourage more human resource-related information, a 5-year time span (from 2005 to 2009) was considered. Moreover, relying on FTSE100 firms' annual reports from 2005 ensured that we would observe disclosures from the period when international financial reporting standards (IFRS) became mandatory in the UK and the European Union. The sample period also covers the period the Labour government was in power, given that it lost to a coalition of the Conservative and Liberal democrat parties in the 2010 elections, signalling a notable change in political priorities. Similarly, the period of analysis does not address the effects of the introduction of the UK corporate governance code (Financial Reporting Council 2010, 2012), since it would have had an impact on reporting practices involving employees, as one of the major corporate stakeholders. The sample of annual reports was limited to 210 annual reports that met the required data, covering a 5 -year time period (2009-49; 2008-46; 2007-40; 2006-40 and 2005-35). One limitation of the sample selection technique is the possibility of self-selection bias. The sample, however, accounts for a minimum of $26 \%$ to a maximum of $36 \%$ of the total market capitalization of firms listed on the London Stock Exchange (34-44\% of all the FTSE 100 firms) for the sample period. This arguably minimises the possibility of sample selection bias.

\section{Data Collection and content analysis}

To-date, different types of units of measurement have been used in content analysis. These include counts of: words (Li et al. 2008; Subbarao and Zeghal 1997); lines (Abeysekera and Guthrie 2004, 2005); sentences (Abeysekera and Guthrie 2004); and paragraphs (Guthrie et al. 2004). Previous studies have primarily considered the presence or absence of information, frequency of reporting, text size (Abeysekera and Guthrie 2004, 2005; Subbarao and Zeghal 1997), and coverage in terms of breadth (Beattie 2005) of reporting. Very few studies, though, have considered the "depth" of reporting (Bouten et al. 2011), and this has long been recognised a limitation within the literature (Michelon et al. 2015). This is akin to Michelon et al.'s (2015) idea of inferring "managerial orientation" (towards corporate social responsibility) from disclosure data.

Informed by these HRD studies (Abeysekera 2008; Abeysekera and Guthrie 2004, 2005; Ax and Marton 2008; Huang et al. 2013; Subbarao and Zeghal 1997), disclosure themes have been selected and validated via a pilot study of a sample of UK annual reports (20 reports each from 2008 and 2009) prior to the main data collection exercise. A pilot study, which started with a broader list of items (39), helped refine the final disclosure index to a 22 -item list. This was done through an iterative process of classifying and re-classifying items in order to develop the current HRD index, inclusive of its two categories, "sustainable" and "procedural" HRD. The HRD for a particular item is then measured in terms of its presence and absence ( 1 and 0 , respectively), followed by an assessment of the informational availability of HRD items at each level of reporting. Briefly, "objective" refers to the availability of disclosures related to the objectives under each individual HRD item (e.g. our plan is to increase employees' engagement). "Measurement" refers to the availability of disclosures related to measurement criteria to assess under each item (e.g. employee engagement score). "Target" refers to the availability of information regarding the periodic targets under each HRD item (e.g. increase the employee engagement score by $5 \%$ during the year). "Initiative" refers to the availability of disclosures related to the action plans under each HRD item (e.g. organise workshops and training programmes to reinforce and encourage employee engagement). Finally, "achievement" refers to the availability of disclosures related to the periodic achievement of the targets under each HRD item or related outcomes (e.g. this enables the firm to engage employees to deliver to customers and to increase business performance).

Hence, the disclosure score under each HRD item can vary from 0 (no disclosure) up to 5 (comprehensive overall disclosure integrating all the five levels). A comprehensive disclosure (score of 5) for any item in the HRD index reflects the substantive nature of the information, thereby allowing stakeholders and other societal actors to make an informed judgement on the nature of a firm's HR practices (Marr et al. 2004).

\section{Research Model and Measures}

The first research hypothesis is investigated via a descriptive/trend analysis. The second research hypothesis consists of examining the relationship between the firm's employee relation ideology and HRD using multiple regression analysis. Key variables and the measurements used in the model are provided in Table 10 in Appendix.

\section{Dependent Variable}

HRD index data was collected manually via content analysis techniques. In addition to the overall disclosure index (HRD), we have considered two sub-indices in relation to the nature of the disclosure: whether the items are related to 
long-term human resource investment (sustainable HR) or short-term procedural-related disclosures.

\section{Independent Variable}

The independent variable-unitarist or non-unitarist orientation of the firm-is assessed by relying on Brown's (2000) employee relations ideologies. Specifically, the firm's disposition towards a given employee relation ideology is assessed (from 0 to 5) on the basis of the firm's disclosure of its relationship with employee representatives and union activities. This is akin to Michelon et al.'s (2015) idea of inferring "managerial orientation" from disclosure data. A more detailed explanation of how the company addresses employee and union relations will lead to a higher score and thereby reflect a trend towards a unitarist ideology. A lower score (or zero) would, respectively, proxy for a low unitarism or a non-unitarist ideology.

\section{Control Variables}

Relying on prior studies of voluntary disclosure generally, and HRD more specifically, legitimacy and stakeholder perspectives underpin the implications of firm-specific characteristics: firm size (Kadapakkam et al. 1998), IC intensity (Amir and Lev 1996; Li et al. 2012), industry regulation (Lajili and Zéghal 2005, 2006), leverage (Popov 2014), profitability (An et al. 2011), liquidity (Kadapakkam et al. 1998), and employee productivity, and corporate governance variables: board size (Abeysekera 2010), board independence ( $\mathrm{Li}$ et al. 2012), size and the number of meetings of the audit, and remuneration and nomination committees (Cormier et al. 2009). These are hypothesised as control variables for the model investigating the association between the employee relation ideologies and HRD. Financial and governance related variables are collected from annual reports or from the FAME (Bureau Van Dijk) database and described in Table 10 in Appendix.

\section{Research Model}

The multiple regression analysis to test the second research hypothesis takes the form of Eq. 1 illustrated below.

$\mathrm{HRD}_{t}=\beta_{0}+\beta_{1} \mathrm{ER}+\sum_{i=0}^{n} \beta_{i} \mathrm{FV}_{i}+\sum_{j=0}^{n} \beta_{j} \mathrm{CG}_{j}+\varepsilon_{t}$

where HRD, human resource disclosure index; ER, employee relation ideology; FV, firm-specific control variables; $\mathrm{CG}$, corporate governance variables; $\beta_{0}$, constant; $\beta_{1}$, $\beta_{i}, \beta_{j}$, regression coefficients; $\varepsilon_{t}$, residual value.

\section{Data Analysis and Results}

The data analyses include description of the research sample, descriptive analysis assessing the firm-level HRD to test the first research hypothesis, and multiple regression analyses testing for the second research hypothesis. Table 1 provides the results of the descriptive statistics.

\section{HRD by FTSE 100 Firms}

The initial analyses focus on the firms' disposition toward HRD in FTSE 100 firms in terms of: (i) percentage of firms that disclose any information in relation to each of the HRD items measured for each financial year and for the overall sample (Table 2); (ii) mean disclosure score for individual HRD items for each financial year and for the overall sample (Table 3); and (iii) percentage of firms that substantively report for each HRD item, in which case only the firms that report on all five levels or at least 4 levels would qualify as being engaged in substantive reporting (Table 4). Results illustrated in Table 2 reveal that each and every item considered under the disclosure index was seen to be important, albeit to varying extents. The percentage of firms that disclosed the various HRD items over the period appears to be very high and is relatively stable.

Items such as work environment and culture, employee know-how and competency, human resource section and function, employee numbers, employee appreciation, employee involvement, and employee experience were the most popular items to be disclosed by the firms (i.e. all the firms disclosed these items on several occasions). Value added and revenue per employee and HR director committee were the least popular HRD items since less than $50 \%$ of the firms disclosed information on these two aspects.

Furthermore, according to the mean HRD scores over the period (Table 3), both sustainable and procedural HRD increased over time. The majority of most disclosed items related to sustainable HRD (i.e. work environment and culture, employee involvement and engagement, employee training programmes, and employee expenses and pension). The most reported procedural HRD was on employee numbers, and employee health and safety. Most of the least disclosed items, such as HR director committee, employee motivation, and employee featured, related to procedural HRD. Value added or revenue per employee was the least disclosed of all the items. Clearly, however, in terms of the quality of the reported information, more significant variations can be noticed.

In determining the substantive or symbolic nature of the disclosures (Table 4), only two items (health \& safety and employee/involvement engagement) could be classified as 
Table 1 Sample description and descriptive statistics

\begin{tabular}{|c|c|c|c|c|c|}
\hline Variable in the model & Mean & Standard deviation & Median & Skewness & Kurtosis \\
\hline \multicolumn{6}{|l|}{ Firm characteristics } \\
\hline Firm size (£Mn) & $26,954.36$ & $29,199.92$ & $16,920.04$ & 1.99 & 6.32 \\
\hline Firm leverage (ratio) & 9.18 & 15.34 & 2.460 & 1.79 & 6.71 \\
\hline Firm profitability (\%) & 30.98 & 27.59 & 27.22 & 0.04 & 7.11 \\
\hline Firm liquidity (ratio) & 0.85 & 0.58 & 0.76 & 2.66 & 13.89 \\
\hline Value added per human capital (ratio) & 3.44 & 3.02 & 2.80 & 4.36 & 28.10 \\
\hline Employee productivity (ratio) & 0.06 & 0.10 & 0.03 & 3.03 & 13.57 \\
\hline \multicolumn{6}{|l|}{ Corporate governance variables } \\
\hline Board size (no.) & 12.98 & 2.58 & 13.00 & 0.44 & 3.60 \\
\hline Audit committee size (no.) & 4.51 & 1.09 & 4.00 & 0.55 & 3.00 \\
\hline Nomination committee size (no.) & 5.41 & 1.98 & 5.00 & 0.67 & 2.60 \\
\hline Remuneration committee size (no.) & 4.56 & 1.10 & 5.00 & 0.36 & 2.78 \\
\hline Board independence (ratio) & 0.71 & 0.10 & 0.71 & -0.11 & 2.41 \\
\hline Audit committee meetings (no.) & 5.82 & 2.42 & 5.00 & 1.33 & 4.41 \\
\hline Remuneration committee meetings (no.) & 5.60 & 2.21 & 5.00 & 1.01 & 4.44 \\
\hline Nomination committee meetings (no.) & 3.74 & 2.23 & 3.00 & 1.35 & 6.19 \\
\hline \multicolumn{6}{|l|}{ Employee relation ideology } \\
\hline Unitarist employee relation & 1.84 & 1.58 & 2.00 & 0.55 & 2.32 \\
\hline \multicolumn{6}{|l|}{ Disclosure variables } \\
\hline Human resource disclosure & 0.59 & 0.15 & 0.58 & -0.19 & 2.49 \\
\hline Procedural HRD & 0.56 & 0.14 & 0.58 & -0.23 & 2.65 \\
\hline Sustainable HRD & 0.61 & 0.17 & 0.62 & -0.26 & 2.34 \\
\hline
\end{tabular}

Firm size is measured as the natural log of market capitalization in $£$ millions; firm leverage is the ratio between total debt to total equity; firm profitability is measured as the return on equity percentage; the intellectual capital intensity is measured as the value added per human capital or the ratio between the total value added and the human resource expenditure; and employee productivity is the ratio between the net income before minority interest divided by the number of employees

comprehensive and even in such cases, this only applied to $55 \%$ of the surveyed reports. Figure 3 presents a comparative picture of the HRD index (HR sustainable-related and Procedural HRD), presenting HRD items with the highest to lowest mean disclosure values and the highest to lowest percentage of firms substantively reporting under each HRD item. The most reported HRD items in terms of the mean disclosure value are similar to those comprehensively disclosed by a large number of companies. The HRD items, which are higher in terms of the mean disclosure value as well as substantively reported by a large number of firms, are items related to long-term HR investment, with only a few exceptions (Fig. 3). In effect, at the dichotomous measurement stage, HRD practices appear quite frequently across the sample. However, over time and once the depth of disclosure was considered, more selectivity emerged from the disclosures.

Procedural HRD items mostly relate to the categories least reported in terms of the mean HRD value and were substantively disclosed by the least number of firms, indicating that more firms appeared to be involved in a selective disclosure strategy. Several procedural HRD items, such as employee health and safety, and employee diversity and equity, accounted for a larger part of the mean HRD score, reflecting the considerable attention of stakeholders and societal actors on health and safety, and a processual form of moral legitimacy. For certain HRD items, such as value added or revenue per employee and employee experience, selective or non-disclosure was relatively frequent and reflective of a strategy to not reveal the more financial-led metrics of employee contributions (e.g. comparing value-added to average salaries in the company) (Amir and Lev 1996). In other words, there are indications of a more instrumental form of stakeholder management and moral legitimacy seeking practices than of a more ethically driven notion of accountability to stakeholders.

\section{HRD Trend in the UK Context}

As evidence of the corporate response to regulatory attempts by the then Labour government, our results show a clear increase in the number of firms that started to disclose information relating to our HRD items between 2005 and 2006, except for two notable items (HR director committee and value added/revenue per employee). The drops in disclosure in 2007 and 2008 might have been attributable to the 
Table 2 Percentage of firms disclosing any information in relation to the individual HRD items measured for each financial year and for the overall sample

\begin{tabular}{|c|c|c|c|c|c|c|}
\hline Disclosure item & $\begin{array}{l}\% \text { HRD } \\
2005 \\
\text { Out of } 35\end{array}$ & $\begin{array}{l}\% \text { HRD } \\
2006 \\
\text { Out of } 40\end{array}$ & $\begin{array}{l}\% \mathrm{HRD} \\
2007 \\
\text { Out of } 40\end{array}$ & $\begin{array}{l}\% \text { HRD } \\
2008 \\
\text { Out of } 46\end{array}$ & $\begin{array}{l}\% \text { HRD } \\
2009 \\
\text { Out of } 49\end{array}$ & $\begin{array}{l}\% \text { HRD } \\
\text { Total sample } \\
\text { Out of } 210\end{array}$ \\
\hline \multicolumn{7}{|l|}{ Procedural HRD } \\
\hline Employee health and safety & 91.43 & 92.50 & 95.00 & 95.65 & 91.84 & 93.33 \\
\hline Employee diversity and equity issues & 91.43 & 95.00 & 92.50 & 89.13 & 93.88 & 92.38 \\
\hline HR section and HR functions & 97.14 & 100.00 & 100.00 & 100.00 & 100.00 & 99.52 \\
\hline Employee numbers & 97.14 & 100.00 & 97.50 & 100.00 & 97.96 & 98.57 \\
\hline Employee welfare and benefit & 82.86 & 95.00 & 95.00 & 93.48 & 97.96 & 93.33 \\
\hline Employee appreciation & 94.29 & 100.00 & 100.00 & 100.00 & 97.96 & 98.57 \\
\hline Employee satisfaction and loyalty & 85.71 & 97.50 & 92.50 & 86.96 & 95.92 & 91.90 \\
\hline Employee motivation & 80.00 & 90.00 & 80.00 & 82.61 & 85.71 & 83.81 \\
\hline Employee featured & 88.57 & 82.50 & 80.00 & 89.13 & 89.80 & 86.19 \\
\hline HR director committee & 31.43 & 37.50 & 47.50 & 56.52 & 57.14 & 47.14 \\
\hline \multicolumn{7}{|l|}{ Sustainable HRD } \\
\hline Employee involvement & 88.57 & 97.50 & 100.00 & 97.83 & 93.88 & 95.71 \\
\hline Work environment and culture of employees & 100.00 & 97.50 & 97.50 & 100.00 & 100.00 & 99.05 \\
\hline Employee expenses and pension & 85.71 & 95.00 & 87.50 & 95.65 & 97.96 & 92.86 \\
\hline Employee training programme & 97.14 & 87.50 & 95.00 & 91.30 & 95.92 & 93.33 \\
\hline Employee compensation plan including share schemes & 88.57 & 97.50 & 95.00 & 91.30 & 91.84 & 92.86 \\
\hline Employee know-how and competency & 97.14 & 97.50 & 100.00 & 97.83 & 100.00 & 98.57 \\
\hline Education and vocational qualification & 77.14 & 80.00 & 80.00 & 71.74 & 73.47 & 76.19 \\
\hline Employee experience & 94.29 & 95.00 & 92.50 & 95.65 & 100.00 & 95.71 \\
\hline Value-added strategy & 94.29 & 97.50 & 95.00 & 97.83 & 97.96 & 96.67 \\
\hline Career development & 88.57 & 97.50 & 97.50 & 93.48 & 95.92 & 94.76 \\
\hline Value-added/revenue per employee & 25.71 & 30.00 & 22.50 & 23.91 & 22.45 & 24.76 \\
\hline Entrepreneurial spirit and innovation & 85.71 & 85.00 & 95.00 & 84.78 & 89.80 & 88.10 \\
\hline
\end{tabular}

unfavourable economic conditions arising from the financial crisis. There was a generally corresponding increase in procedural and sustainable HRD, indicative of an increase in the breadth of disclosure as well. According to the annual averages presented in Table 5, with the exception of 2008, on average, the HRD indices have increased over the period, albeit marginally. This can be seen as an attempt to respond to stakeholder and government-led demands to engage with the Accounting for People agenda, and is in accordance with the stakeholder salience and moral legitimacy perspectives (Abeysekera 2008; Abeysekera and Guthrie 2004, 2005; Ax and Marton 2008; McCracken et al. 2018).

The overall HRD index revealed an increasing trend in terms of the amount disclosed. This indicates that the UK's policy attempts to formally recognise human resources has had a positive, albeit selective, impact on some aspects of HRD in the annual reports. In addition, the eventual failure of the government's attempts to formalise an HRD framework could have signalled to UK firms that such disclosure has become less important and/or societal attention has shifted. Similar organisational responses were noted in the case of Soobaroyen and Ntim (2013). Over the period under study however, it can be concluded that the nature of the disclosures has gradually shifted from a selective form to a more comprehensive one, and more substantive information is disclosed in the annual reports (Marr et al. 2004), thereby supporting $H 1$, and reflecting stakeholder salience and moral legitimacy perspectives. In particular, the existence of more substantive information in relation to sustainable HRD suggests that there has been a change in the salience of the stakeholder arising from the government's disposition towards HR reforms. At the same time, organisational variations do exist, and the next section attempts to explain this changing behaviour by considering the relationship between the company's employee relation ideology and HRD.

\section{Employee Relation Ideology and Substantive Disclosure}

A complete set of regression diagnostics was performed before hypothesis testing. The correlation matrix is presented in Table 6 . All the financial variables are winsorized 
Table 3 Mean disclosure score value for individual HRD item for each financial year and for the overall sample

\begin{tabular}{|c|c|c|c|c|c|c|}
\hline HRD items & $\begin{array}{l}\text { Mean } \\
\text { score } \\
\text { overall }\end{array}$ & Mean score 2005 & Mean score 2006 & Mean score 2007 & Mean score 2008 & Mean score 2009 \\
\hline \multicolumn{7}{|l|}{ Procedural HRD } \\
\hline Employee health and safety & 3.619 & 3.343 & 3.475 & 3.550 & 3.674 & 3.939 \\
\hline $\begin{array}{l}\text { Employee diversity and equity } \\
\text { issues }\end{array}$ & 3.457 & 3.057 & 3.350 & 3.700 & 3.370 & 3.714 \\
\hline HR section and HR functions & 3.576 & 2.943 & 3.575 & 4.075 & 3.544 & 3.653 \\
\hline Employee numbers & 3.729 & 3.400 & 3.575 & 3.8 & 3.761 & 4.000 \\
\hline Employee welfare and benefit & 3.300 & 2.600 & 3.000 & 3.425 & 3.544 & 3.714 \\
\hline Employee appreciation & 2.948 & 2.743 & 3.100 & 3.350 & 2.544 & 3.020 \\
\hline Employee satisfaction and loyalty & 2.705 & 2.314 & 2.55 & 2.825 & 2.804 & 2.918 \\
\hline Employee motivation & 1.957 & 1.771 & 1.95 & 1.900 & 1.957 & 2.143 \\
\hline Employee featured & 1.791 & 1.800 & 1.725 & 1.700 & 1.848 & 1.857 \\
\hline HR director committee & 0.891 & 0.429 & 0.725 & 0.975 & 0.913 & 1.265 \\
\hline \multicolumn{7}{|l|}{ Sustainable HRD } \\
\hline Employee involvement/engagement & 3.848 & 3.314 & 3.975 & 4.025 & 3.870 & 3.959 \\
\hline $\begin{array}{l}\text { Work environment and culture of } \\
\text { employees }\end{array}$ & 3.895 & 3.629 & 4.000 & 4.100 & 3.717 & 4.000 \\
\hline Employee expenses and pension & 3.681 & 3.571 & 3.725 & 3.350 & 3.826 & 3.857 \\
\hline Employee training programme & 3.586 & 3.257 & 3.475 & 3.700 & 3.435 & 3.959 \\
\hline $\begin{array}{l}\text { Employee compensation plan } \\
\text { including share schemes }\end{array}$ & 3.500 & 2.943 & 3.450 & 3.675 & 3.587 & 3.714 \\
\hline $\begin{array}{l}\text { Employee know-how and compe- } \\
\text { tency }\end{array}$ & 3.467 & 2.829 & 3.550 & 3.600 & 3.544 & 3.674 \\
\hline $\begin{array}{l}\text { Education and vocational qualifica- } \\
\text { tion }\end{array}$ & 2.495 & 2.371 & 2.675 & 2.775 & 2.217 & 2.469 \\
\hline Employee experience & 2.767 & 2.629 & 2.525 & 2.85 & 2.522 & 3.225 \\
\hline Value-added strategy & 3.267 & 2.714 & 3.225 & 3.35 & 3.196 & 3.694 \\
\hline Career development & 3.310 & 2.571 & 3.35 & 3.525 & 3.326 & 3.612 \\
\hline Value-added/revenue per employee & 0.510 & 0.514 & 0.575 & 0.425 & 0.435 & 0.591 \\
\hline $\begin{array}{l}\text { Entrepreneurial spirit and innova- } \\
\text { tion }\end{array}$ & 2.048 & 2.057 & 2.050 & 2.125 & 2.087 & 1.939 \\
\hline
\end{tabular}

at the 1st and 99th percentile in order to minimise the effect of possible outliers. Results of the multiple linear regression to test for $H 2$ are summarised in Table 7. The main analysis takes into account the year and the firm fixed-effects. Results for the robustness check with random-effects model and the pooled-linear regression are presented in Tables 8 and 9, respectively.

According to the results reported in Table 6, there is a strong positive association between the extent of the unitarist employee relation ideology of the firm and the level of HRD. The results also hold for categorical HRD indices for procedural and sustainable HRDs. This implies that $\mathrm{H} 2$ is supported, and thus offers new insight in terms of how a firm's managerial orientation towards a unitarist employee relations ideology can motivate more substantive and comprehensive disclosures. As per our theoretical expectations, an environment that is characterised by both mutual dialogue, respect, and trust between management/owners and employee unions/labour (Brown 2000), and agreement on common objectives results in management being more likely to engage HRDs that are substantive in nature. The firm-specific and the corporate governance related control variables used in previous empirical studies explaining the non-financial disclosure in general, however, did not reveal any significant association with HRD when firm- and yearfixed-effects were accounted for. This suggests that HRD, compared to other social and environmental disclosures, is less (if at all) influenced by traditional organisational factors. However, when relying on a random-effects model and pooled-linear regressions, the firm-specific variables (firm size, liquidity, and profitability), governance related control variables (board independence, remuneration committee size, and nomination committee meeting), and the financial crisis dummy variable are significantly associated with HRD. 


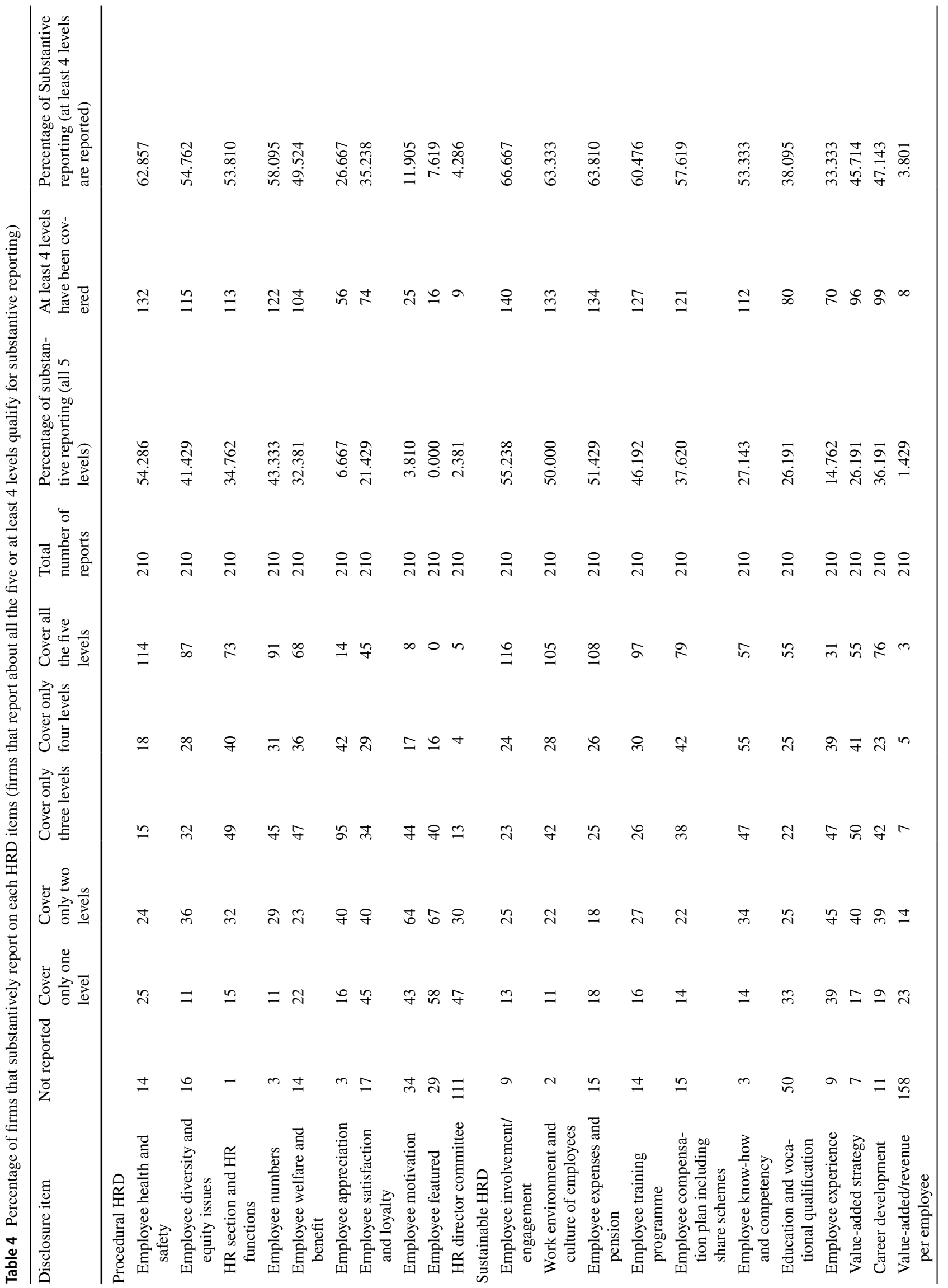




\section{Discussion}

In the current study, we consider HRD in isolation from other forms of disclosures (e.g. intellectual capital) (Abeysekera 2010; An et al. 2011; Li et al. 2008, 2012), and we examine firm-level HRD practice at the time of UK reforms that aimed to foster higher levels of corporate accountability regarding HR practices (CIPD 2017; McCracken et al. 2018). Researchers have observed that there is a significant improvement in HRD over time, particularly in terms of the sustainable HR items (DTI 2003a, b; Roslender and Stevenson 2009). Distinctively, we have also established that a company's employee relation ideology is associated with HRD.

Furthermore, the unitarist employee relation ideology claim of a supportive relationship between employees and employers leading to more comprehensive, transparent, and uniform HRD that reflects a mutual engagement between key stakeholders is evidenced/confirmed by the firms' adoption of higher levels of substantive HRD (Brown 2000; Ashforth and Gibbs 1990). The significant positive association established through the current empirical analysis holds and supports this proposition; however, the level of disclosure in relation to all individual HRD items suggests that there is still room for significant improvement in practice.

A comparison of the findings with previous empirical studies revealed mixed implications. In certain instances, the findings offer support for the previous empirical evidence (Subbarao and Zeghal 1997); however, there were also contradictory results for a range of different reasons. The most substantively disclosed items in the current study (such as employee benefit, employee numbers, and HRM and function-related information) and the least substantively disclosed items (such as HR director involvement and HR director committee) were recognised in a similar manner by Subbarao and Zeghal (1997). The progressive improvement in HRD from symbolic to substantive revealed that the levels of disclosure for HR investment-related items have increased since 1996, providing a comprehensive picture on items recognised as most reported in the UK context. However, even though the frequency and the text size/volume were higher for some items, such as employee appreciation and employee motivation, the comprehensive nature of the disclosures relating to them had not visibly improved. These findings imply that the financial reports have tended to consider procedural HRD items at the symbolic compliance level when compared with substantively reported HR sustainable-related items; thus evidence of an instrumental stakeholder management strategy at play is combined with an attempt to maintain moral legitimacy.

As an example, the disclosure of employee contribution to the firm's value added has not been disclosed by UK firms 


\begin{tabular}{|c|c|c|}
\hline HRD index categories & Mean disclosure value: most to least disclosure & Most to least substantive disclosure by firms \\
\hline $\begin{array}{c}\text { HR investment-related } \\
\text { Work environment and culture of employees } \\
\text { Employee involvement/engagement } \\
\text { Employee expenses and pension } \\
\text { Employee training programme } \\
\text { Employee compensation plan including share } \\
\text { schemes } \\
\text { Employee know-how and competency } \\
\text { Career development } \\
\text { Value-added strategy } \\
\text { Employee experience } \\
\text { Education and vocational qualification } \\
\text { Entrepreneurial spirit and innovation } \\
\text { Value added/revenue per employee }\end{array}$ & $\begin{array}{c}\text { Most disclosures } \\
\text { Work environment and culture of employees } \\
\text { Employee involvement/engagement } \\
\text { Employee numbers } \\
\text { Employee expenses and pension } \\
\text { Employee health and safety } \\
\text { Employee training programme } \\
\text { HR section and HR functions } \\
\text { Employee compensation plan including share } \\
\text { schemes } \\
\text { Employee know-how and competency } \\
\text { Employee diversity and equity issues } \\
\text { Career development } \\
\text { Employee welfare and benefit } \\
\text { Value-added strategy }\end{array}$ & $\begin{array}{c}\text { Substantive disclosure by most \% of firms } \\
\text { Employee involvement/engagement } \\
\text { Employee health and safety } \\
\text { Employee expenses and pension } \\
\text { Work environment and culture of employees } \\
\text { Employee training programme } \\
\text { Employee numbers } \\
\text { Employee diversity and equity issues } \\
\text { Employee compensation plan including share } \\
\text { schemes } \\
\text { Career development } \\
\text { HR section and HR functions } \\
\text { Employee welfare and benefit } \\
\text { Employee know-how and competency } \\
\text { Value-added strategy }\end{array}$ \\
\hline $\begin{array}{c}\text { Procedural HRD } \\
\text { Employee numbers } \\
\text { Employee health and safety } \\
\text { HR section and HR functions } \\
\text { Employee diversity and equity issues } \\
\text { Employee welfare and benefit } \\
\text { Employee appreciation } \\
\text { Employee satisfaction and loyalty } \\
\text { Employee motivation } \\
\text { Employee featured } \\
\text { HR director committee }\end{array}$ & $\begin{array}{c}\text { Least disclosures } \\
\text { Employee appreciation } \\
\text { Employee experience } \\
\text { Employee satisfaction and loyalty } \\
\text { Education and vocational qualification } \\
\text { Entrepreneurial spirit and innovation } \\
\text { Employee motivation } \\
\text { Employee featured } \\
\text { HR director committee } \\
\text { Value added/revenue per employee }\end{array}$ & $\begin{array}{l}\text { Substantive disclosure by least \% of firms } \\
\text { Education and vocational qualification } \\
\text { Employee satisfaction and loyalty } \\
\text { Employee experience } \\
\text { Entrepreneurial spirit and innovation } \\
\text { Employee appreciation } \\
\text { Employee motivation } \\
\text { HR director committee } \\
\text { Value added/revenue per employee } \\
\text { Employee featured }\end{array}$ \\
\hline
\end{tabular}

Fig. 3 Comparative presentation: HRD index categories, mean disclosure value categories and substantive/symbolic disclosure categories

Table 5 Overall HRD index value trend in comparison with procedural and sustainable HRD indices

\begin{tabular}{llllllll}
\hline Variable & Statistics & Overall sample & 2005 & 2006 & 2007 & 2008 & 2009 \\
\hline HRD index (ratio) & Mean & 0.585 & 0.516 & 0.578 & 0.607 & 0.579 & 0.627 \\
& St Dev & 0.147 & 0.148 & 0.135 & 0.136 & 0.154 & 0.145 \\
Procedural HRD index (ratio) & Mean & 0.560 & 0.488 & 0.541 & 0.586 & 0.559 & 0.605 \\
& St Dev & 0.138 & 0.134 & 0.129 & 0.121 & 0.145 & 0.136 \\
Sustainable HRD index (ratio) & Mean & 0.606 & 0.540 & 0.609 & 0.625 & 0.596 & 0.645 \\
& St Dev & 0.174 & 0.174 & 0.159 & 0.168 & 0.185 & 0.167 \\
\hline
\end{tabular}

The disclosure indices are calculated as the ratio between the summation of the actual disclosure scores for all the items considered under a particular index (22 items for HRD index, 10 items for Procedural HRD index and 12 items for Sustainable HRD index) and the summation of the ideal substantive disclosure for all the items considered under a particular index $(5 * 22$ for HRD index, $5 * 10$ for Procedural HRD index and $5^{*} 12$ for Sustainable HRD index). The value ranges from 0 to 1 . The higher the value of the index, the more substantive the HRD is since 1993/1994 (Subbarao and Zeghal 1997). In spite of it being categorised as sustainable HR-related disclosure, the results indicate that only a handful of firms have reported this item in their annual reports. Confirming this previous evidence of intentional exclusions (Burchell et al. 1985), out of 210 annual reports in the study, 158 reports did not have any information on employee contribution to firm value added, and only three reports out of 210 appear to have substantive disclosure practices (i.e. reporting on all of the five levels). Whilst higher employee contribution to firm value creation is recognised as a sustainable business practice (Vithana et al. 2018), the exclusion of the value-added information was deemed intentional (Burchell et al. 1985) as a means to avoid this information falling in the hands of trade unions. Arguably, the instrumental stakeholder perspective supports the view that companies may also seek to "manage" stakeholders by avoiding the disclosure of information deemed to be sensitive in the management of employee relations. There has been an increasing recognition of some aspects, such as health and safety, employee diversity and equity issues. Companies evidently appear to be seeking to achieve consequential and processual legitimacy as a result of the existing regulatory framework on health and safety, equal employment opportunity, and diversity related aspects (Adams and Harte 2000). This offers support for the findings of the ACCA (2009) study on HRD in annual reports. 


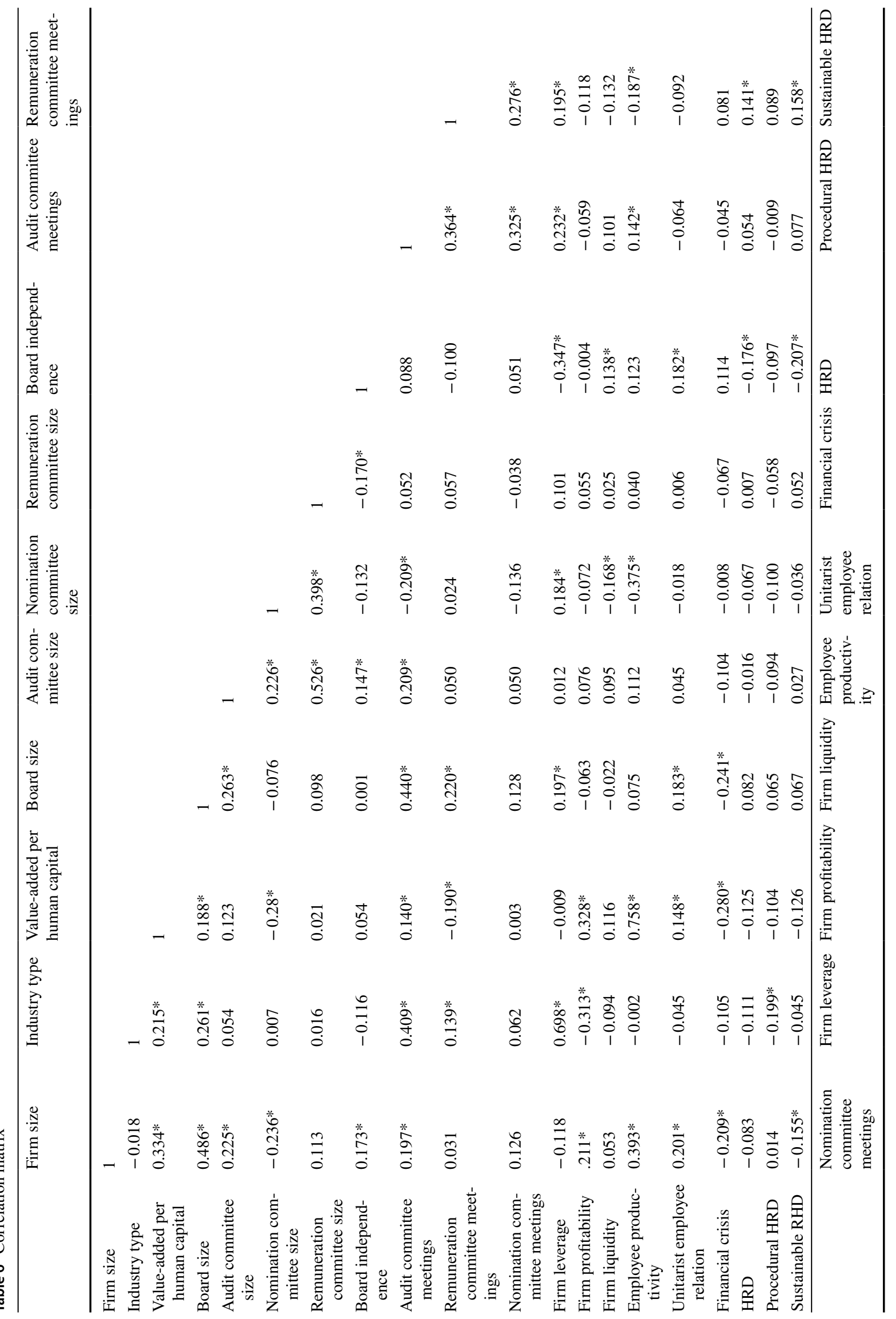




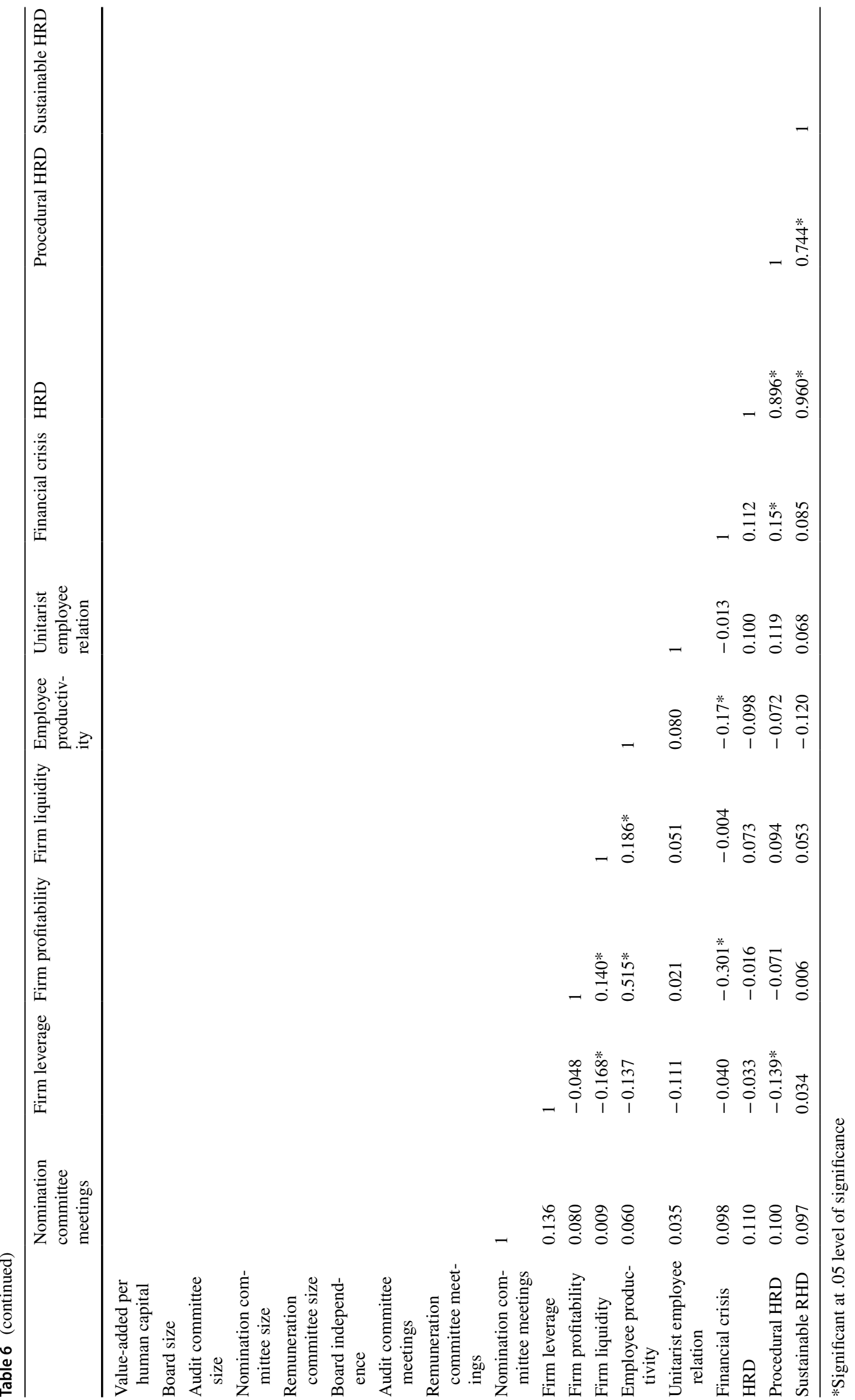


Table 7 Results of multiple regression analysis with fixedeffects

\begin{tabular}{|c|c|c|c|}
\hline Variable & $\begin{array}{l}\text { Human resource } \\
\text { disclosure }\end{array}$ & Procedural HRD & Sustainable HRD \\
\hline Constant & $\begin{array}{l}0.209 \\
(0.324)\end{array}$ & $\begin{array}{l}0.168 \\
(0.319)\end{array}$ & $\begin{array}{l}0.245 \\
(0.393)\end{array}$ \\
\hline \multicolumn{4}{|l|}{ Firm-specific variables } \\
\hline Firm size $(£ M n)$ & $\begin{array}{l}0.080 \\
(0.066)\end{array}$ & $\begin{array}{l}0.099 \\
(0.065\end{array}$ & $\begin{array}{l}0.063 \\
(0.080)\end{array}$ \\
\hline Firm leverage & $\begin{array}{l}0.001 \\
(0.001)\end{array}$ & $\begin{array}{l}0.002 \\
(0.001)\end{array}$ & $\begin{array}{l}0.001 \\
(0.002)\end{array}$ \\
\hline Firm profitability & $\begin{array}{l}0.0002 \\
(0.0004)\end{array}$ & $\begin{array}{l}0.0002 \\
(0.0004)\end{array}$ & $\begin{array}{l}0.0002 \\
(0.001)\end{array}$ \\
\hline Firm liquidity & $\begin{array}{l}0.022 \\
(0.025)\end{array}$ & $\begin{array}{l}0.0095 \\
(0.024)\end{array}$ & $\begin{array}{l}0.033 \\
(0.030)\end{array}$ \\
\hline Value-added per human capital & $\begin{array}{l}0.009 \\
(0.009)\end{array}$ & $\begin{array}{l}0.012 \\
(0.0097)\end{array}$ & $\begin{array}{l}0.077 \\
(0.012)\end{array}$ \\
\hline Employee productivity & $\begin{array}{l}-0.081 \\
(0.235)\end{array}$ & $\begin{array}{l}-0.171 \\
(0.232)\end{array}$ & $\begin{array}{l}-0.005 \\
(0.285)\end{array}$ \\
\hline \multicolumn{4}{|l|}{ Crisis dummy } \\
\hline Financial crisis dummy & $\begin{array}{l}0.018 \\
(0.019)\end{array}$ & $\begin{array}{l}0.031^{*} \\
(0.019)\end{array}$ & $\begin{array}{l}0.007 \\
(0.023)\end{array}$ \\
\hline \multicolumn{4}{|l|}{ Corporate governance variables } \\
\hline Board size & $\begin{array}{l}0.002 \\
(0.007)\end{array}$ & $\begin{array}{l}0.0001 \\
(0.007)\end{array}$ & $\begin{array}{l}0.004 \\
(0.008)\end{array}$ \\
\hline Audit committee size & $\begin{array}{l}-0.014 \\
(0.011)\end{array}$ & $\begin{array}{l}-0.026^{* *} \\
(0.011)\end{array}$ & $\begin{array}{l}-0.004 \\
(0.013)\end{array}$ \\
\hline Nomination committee size & $\begin{array}{l}-0.004 \\
(0.009)\end{array}$ & $\begin{array}{l}0.002 \\
(0.008)\end{array}$ & $\begin{array}{l}-0.009 \\
(0.010)\end{array}$ \\
\hline Remuneration committee size & $\begin{array}{l}-0.008 \\
(0.013)\end{array}$ & $\begin{array}{l}-0.009 \\
(0.013)\end{array}$ & $\begin{array}{l}-0.007 \\
(0.016)\end{array}$ \\
\hline Board independence & $\begin{array}{l}-0.030 \\
(0.171)\end{array}$ & $\begin{array}{l}0.063 \\
(0.168)\end{array}$ & $\begin{array}{l}-0.107 \\
(0.207)\end{array}$ \\
\hline Audit committee meetings & $\begin{array}{l}0.002 \\
(0.009)\end{array}$ & $\begin{array}{l}-0.010 \\
(0.009)\end{array}$ & $\begin{array}{l}0.012 \\
(0.011)\end{array}$ \\
\hline Remuneration committee meetings & $\begin{array}{l}0.003 \\
(0.005)\end{array}$ & $\begin{array}{l}0.004 \\
(0.005)\end{array}$ & $\begin{array}{l}0.003 \\
(0.007)\end{array}$ \\
\hline Nomination committee meetings & $\begin{array}{l}0.004 \\
(0.004)\end{array}$ & $\begin{array}{l}0.002 \\
(0.004)\end{array}$ & $\begin{array}{l}0.006 \\
(0.005)\end{array}$ \\
\hline \multicolumn{4}{|l|}{ Employee relation ideology status } \\
\hline Unitarist employee relation & $\begin{array}{l}0.022 * * \\
(0.007)\end{array}$ & $\begin{array}{l}0.017 * * \\
(0.007)\end{array}$ & $\begin{array}{l}0.026 * * * \\
(0.009)\end{array}$ \\
\hline Year-effects & Yes & Yes & Yes \\
\hline Firm fixed-effects & Yes & Yes & Yes \\
\hline$R^{2}$ & 0.012 & 0.0112 & 0.0107 \\
\hline Sample size & 203 & 203 & 203 \\
\hline
\end{tabular}

Firm size is measured as the natural log of market capitalization in £millions; firm leverage is the ratio between total debt to total equity; firm profitability is measured as the return on equity; the intellectual capital intensity is measured as the value added per human capital or the ratio between the total value added and the human resource expenditure; and employee productivity is the ratio between the net income before minority interest divided by the number of employees

***Significant at 0.01 level of significance; **significant at 0.05 level of significance; *significant at 0.10 level of significance
A comparison of the results with the previous empirical evidence reveals that there are many unrecognised items (i.e. in relation to the UK) ( $\mathrm{Li}$ et al. 2008) and in a developing economy context (Abeysekera 2008). As an example, HRD items directly related to the employee development, such as educational and vocational qualifications, entrepreneurial spirit and innovations, and employee motivation, represent the foundation upon which a firm's investment in $\mathrm{HC}$ 
Table 8 Results of multiple regression analysis with random-effects

\begin{tabular}{|c|c|c|c|}
\hline Variable & $\begin{array}{l}\text { Human resource } \\
\text { disclosure }\end{array}$ & Procedural HRD & Sustainable HRD \\
\hline Constant & $\begin{array}{l}0.806 * * * \\
(0.185)\end{array}$ & $\begin{array}{l}0.606 * * * \\
(0.177)\end{array}$ & $\begin{array}{l}0.996 * * * \\
(0.218)\end{array}$ \\
\hline Firm size $(£ M n)$ & $\begin{array}{l}-0.022 \\
(0.041)\end{array}$ & $\begin{array}{l}0.029 \\
(0.039)\end{array}$ & $\begin{array}{l}-0.069 \\
(0.048)\end{array}$ \\
\hline Industry type & $\begin{array}{l}-0.056 \\
(0.047)\end{array}$ & $\begin{array}{l}-0.090 * * \\
(0.045)\end{array}$ & $\begin{array}{l}-0.026 \\
(0.055)\end{array}$ \\
\hline Firm leverage & $\begin{array}{l}-0.0001 \\
(0.001)\end{array}$ & $\begin{array}{l}0.0003 \\
(0.001)\end{array}$ & $\begin{array}{l}-0.001 \\
(0.001)\end{array}$ \\
\hline Firm profitability & $\begin{array}{l}0.0002 \\
(0.0003)\end{array}$ & $\begin{array}{l}0.0001 \\
(0.0004)\end{array}$ & $\begin{array}{l}0.0003 \\
(0.0004)\end{array}$ \\
\hline Firm liquidity & $\begin{array}{l}0.030^{*} \\
(0.017)\end{array}$ & $\begin{array}{l}0.022 \\
(0.017)\end{array}$ & $\begin{array}{l}0.039^{*} \\
(0.021)\end{array}$ \\
\hline Value-added per human capital & $\begin{array}{l}0.002 \\
(0.005)\end{array}$ & $\begin{array}{l}0.002 \\
(0.005)\end{array}$ & $\begin{array}{l}0.001 \\
(0.006)\end{array}$ \\
\hline Employee productivity & $\begin{array}{l}-0.028 \\
(0.172)\end{array}$ & $\begin{array}{l}-0.033 \\
0.166\end{array}$ & $\begin{array}{l}-0.024 \\
(0.203)\end{array}$ \\
\hline Financial crisis dummy & $\begin{array}{l}0.024 \\
(0.017)\end{array}$ & $\begin{array}{l}0.032^{*} \\
(0.018)\end{array}$ & $\begin{array}{l}0.017 \\
(0.021)\end{array}$ \\
\hline Board size & $\begin{array}{l}0.004 \\
(0.005)\end{array}$ & $\begin{array}{l}0.002 \\
(0.005)\end{array}$ & $\begin{array}{l}0.006 \\
(0.006)\end{array}$ \\
\hline Audit committee size & $\begin{array}{l}-0.010 \\
(0.010)\end{array}$ & $\begin{array}{l}-0.021 * * \\
(0.010)\end{array}$ & $\begin{array}{l}-0.001 \\
(0.012)\end{array}$ \\
\hline Nomination committee size & $\begin{array}{l}-0.004 \\
(0.007)\end{array}$ & $\begin{array}{l}-0.001 \\
(0.007)\end{array}$ & $\begin{array}{l}-0.007 \\
(0.008)\end{array}$ \\
\hline Remuneration committee size & $\begin{array}{l}-0.001 \\
(0.011)\end{array}$ & $\begin{array}{l}-0.003 \\
(.011)\end{array}$ & $\begin{array}{l}0.0004 \\
(0.013)\end{array}$ \\
\hline Board independence & $\begin{array}{l}-0.293 * * \\
(0.123)\end{array}$ & $\begin{array}{l}-0.216^{*} \\
(0.119)\end{array}$ & $\begin{array}{l}-0.377^{* * *} \\
(0.145)\end{array}$ \\
\hline Audit committee meetings & $\begin{array}{l}0.000 \\
(0.006)\end{array}$ & $\begin{array}{l}-0.002 \\
(0.006)\end{array}$ & $\begin{array}{l}0.001 \\
(0.007)\end{array}$ \\
\hline Remuneration committee meetings & $\begin{array}{l}0.005 \\
(0.005)\end{array}$ & $\begin{array}{l}0.003 \\
(0.005)\end{array}$ & $\begin{array}{l}0.007 \\
(0.006)\end{array}$ \\
\hline Nomination committee meetings & $\begin{array}{l}0.004 \\
(0.004)\end{array}$ & $\begin{array}{l}0.003 \\
(0.004)\end{array}$ & $\begin{array}{l}0.005 \\
(0.005)\end{array}$ \\
\hline Unitarist employee relation & $\begin{array}{l}0.019 * * * \\
(0.006)\end{array}$ & $\begin{array}{l}0.016^{* * *} \\
(0.006)\end{array}$ & $\begin{array}{l}0.021 * * * \\
(0.008)\end{array}$ \\
\hline$R^{2}$ & 0.1399 & 0.1333 & 0.1564 \\
\hline Sample size & 203 & 203 & 203 \\
\hline
\end{tabular}

Firm size is measured as the natural log of market capitalization in $£$ millions; firm leverage is the ratio between total debt to total equity; firm profitability is measured as the return on equity; the intellectual capital intensity is measured as the value added per human capital or the ratio between the total value added and the human resource expenditure; and employee productivity is the ratio between the net income before minority interest divided by the number of employees

***Significant at 0.01 level of significance; **significant at 0.05 level of significance; *significant at 0.10 level of significance is built. Therefore, a symbolic or low recognition of these elements implies an inadequate consideration of longerterm human resource investment. At the same time, these variations in the findings could be attributable to the differences in the content analysis frameworks used to capture HRD, and in particular, previous studies focused more on the frequency rather than the depth of the reported information (McCracken et al. 2018). Hence, reporting may have been more symbolic than substantive and yet scored higher in terms of the frequency or the sentence count, which we address in this paper. The findings indicate that, on the one hand, HRD items relating to the direct investment in human resources (such as employee education, experience, training and development), and HRD items relating to the final outcome of this investment (such as employee value added), and other financial attributes related to HRM (such as revenue/ 
Table 9 Results of multiple regression analysis with pooledlinear regression

\begin{tabular}{|c|c|c|c|}
\hline Variable & $\begin{array}{l}\text { Human resource } \\
\text { disclosure }\end{array}$ & Procedural HRD & Sustainable HRD \\
\hline Constant & $\begin{array}{l}0.890 * * * \\
(0.138)\end{array}$ & $\begin{array}{l}0.693 * * * \\
(0.140)\end{array}$ & $\begin{array}{l}1.05^{* * *} \\
(0.164)\end{array}$ \\
\hline Firm size (£Mn) & $\begin{array}{l}-0.063^{* *} \\
(0.031)\end{array}$ & $\begin{array}{l}-.006 \\
(0.030)\end{array}$ & $\begin{array}{l}-0.112 * * * \\
(0.035)\end{array}$ \\
\hline Industry type & $\begin{array}{l}-0.028 \\
(0.038)\end{array}$ & $\begin{array}{l}-0.062 * \\
(0.034)\end{array}$ & $\begin{array}{l}-0.001 \\
(0.047)\end{array}$ \\
\hline Firm leverage & $\begin{array}{l}-0.001 \\
(0.0009)\end{array}$ & $\begin{array}{l}-0.001 \\
(0.001)\end{array}$ & $\begin{array}{l}-0.002 \\
(0.001)\end{array}$ \\
\hline Firm profitability & $\begin{array}{l}-0.0001 \\
(0.0004)\end{array}$ & $\begin{array}{l}-0.001 \\
(0.0004)\end{array}$ & $\begin{array}{l}0.0002 \\
(0.0005)\end{array}$ \\
\hline Firm liquidity & $\begin{array}{l}0.053 * * * \\
(0.014)\end{array}$ & $\begin{array}{l}0.045^{* * *} \\
(0.013)\end{array}$ & $\begin{array}{l}0.060 * * * \\
(0.017)\end{array}$ \\
\hline Value-added per human capital & $\begin{array}{l}0.0003 \\
(0.004)\end{array}$ & $\begin{array}{l}0.001 \\
(0.005)\end{array}$ & $\begin{array}{l}0.00003 \\
(0.004)\end{array}$ \\
\hline Employee productivity & $\begin{array}{l}-0.051 \\
(0.142)\end{array}$ & $\begin{array}{l}-0.039 \\
(0.133)\end{array}$ & $\begin{array}{l}-0.061 \\
(0.167)\end{array}$ \\
\hline Financial crisis dummy & $\begin{array}{l}0.035 \\
(0.023)\end{array}$ & $\begin{array}{l}0.039 * \\
(0.022)\end{array}$ & $\begin{array}{l}0.032 \\
(0.026)\end{array}$ \\
\hline Board size & $\begin{array}{l}0.013 * * * \\
(0.004)\end{array}$ & $\begin{array}{l}0.009 * * \\
(0.004)\end{array}$ & $\begin{array}{l}0.015 * * * \\
(0.005)\end{array}$ \\
\hline Audit committee size & $\begin{array}{l}0.002 \\
(0.013)\end{array}$ & $\begin{array}{l}-0.005 \\
(0.012)\end{array}$ & $\begin{array}{l}0.008 \\
(0.015)\end{array}$ \\
\hline Nomination committee size & $\begin{array}{c}-0.008 \\
(0.006)\end{array}$ & $\begin{array}{l}-0.006 \\
(0.006)\end{array}$ & $\begin{array}{l}-0.010 \\
(0.007)\end{array}$ \\
\hline Remuneration committee size & $\begin{array}{l}0.005 \\
(0.013)\end{array}$ & $\begin{array}{l}-0.002 \\
(0.012)\end{array}$ & $\begin{array}{l}0.010 \\
(0.016)\end{array}$ \\
\hline Board independence & $\begin{array}{l}-0.412 * * * \\
(0.122)\end{array}$ & $\begin{array}{l}-.343 * * * \\
(.118)\end{array}$ & $\begin{array}{l}-0.470 * * * \\
(0.139)\end{array}$ \\
\hline Audit committee meetings & $\begin{array}{l}-0.005 \\
(0.005)\end{array}$ & $\begin{array}{l}-0.002 \\
(0.004)\end{array}$ & $\begin{array}{l}-0.007 \\
(0.007)\end{array}$ \\
\hline Remuneration committee meetings & $\begin{array}{l}0.008 \\
(0.005)\end{array}$ & $\begin{array}{l}0.004 \\
(0.005)\end{array}$ & $\begin{array}{l}0.012^{* *} \\
(0.006)\end{array}$ \\
\hline Nomination committee meetings & $\begin{array}{l}0.008 * * \\
(0.004)\end{array}$ & $\begin{array}{l}0.007 * \\
(0.004)\end{array}$ & $\begin{array}{l}0.009 * * \\
(0.0045)\end{array}$ \\
\hline Unitarist employee relation & $\begin{array}{l}0.012 * \\
(0.007)\end{array}$ & $\begin{array}{l}0.011 * \\
(0.006)\end{array}$ & $\begin{array}{l}0.013 * \\
(0.0078)\end{array}$ \\
\hline$R^{2}$ & 0.2005 & 0.2005 & 0.1988 \\
\hline Sample size & 203 & 203 & 203 \\
\hline
\end{tabular}

Firm size is measured as the natural log of market capitalization in $£$ millions; firm leverage is the ratio between total debt to total equity; firm profitability is measured as the return on equity; the intellectual capital intensity is measured as the value added per human capital or the ratio between the total value added and the human resource expenditure; and employee productivity is the ratio between the net income before minority interest divided by the number of employees

***Significant at 0.01 level of significance; **significant at 0.05 level of significance; *significant at 0.10 level of significance profit per employee, and employee share and share option schemes, among others), were among the least reported items. On the other hand, procedural HRD items, relating to the organisational HR function, such as employee numbers, HR section and HR function, and employee diversity and equity, were among the most reported. In some ways, this reveals that in terms of HRDs, firms have taken a less than fully comprehensive approach.

\section{Conclusion}

Our research questions focused on (i) exploring the specific practice of sustainable and procedural corporate HRD in the wake of HRD reforms that have been pursued in the UK context, and (ii) the extent to which HRD is associated with the company's employee relation ideology (unitarist versus non-unitarist-pluralist/radicalist ideology), as a reflection 
of managerial/organisational intention towards employees. We argue that HRD is motivated by a theoretical frame that is bound by instrumental stakeholder theory and salience, together with the tenets of moral legitimacy (consequential and processual forms). Our main findings are thus twofold. First, our results suggest that HRDs have become more substantive over time in terms of providing more in-depth and coherent forms of disclosure, although selective reporting remains. Second, we show that a more unitarist employee relation ideology leads to a comprehensive form of HRDs.

This study seeks to contribute to the extant literature in several ways. First, we provide evidence of UK HRD practice in the aftermath of a notable reform and the disposition (and potential) of corporate entities towards the human capital agenda - an issue which is crucial in a number of contemporary reporting models (e.g. Global Reporting Initiative; Integrated Reporting; UN Sustainable Development Goals) and has renewed calls for human resource accounting (CIPD 2015). Second, the disclosure index developed in the paper provides a methodological tool to assess HRD practice in different settings that is sufficiently detailed and separate from the mainstream notions of IC to enable a more focused assessment of a firm's disposition towards HRD.

The methodology of the current study is novel in terms of designing an index to capture both the depth and breadth of the HRD practice, which is an improvement to the usual dichotomous scoring adopted in the larger HRD/ IC literature (e.g. McCracken et al. 2018; Day and Woodward 2004). This method has ensured that comprehensive HRD practices are appropriately captured. An in-depth analysis of the depth and breadth of HRD also concludes that not all the HRD items appear to be substantively disclosed, owing to a strategic approach that is either concerned about the impact of stakeholder salience and/or by the perception that companies are not sufficiently responding to societal expectations about the status of employees in the UK context of instrumental stakeholder and moral legitimacy. But, there are still important HRD items that are not well recognised (i.e. the stagnant HRD scores relating to value added per employee).

There are two related ethical implications arising from the HRD findings. Voluntary disclosure behaviours framed by the instrumental stakeholder, and stakeholder salience and moral legitimacy perspectives suggest that the disclosure process continues to reflect a largely unilateral, managerial-led, process, arguably with a relatively limited level of ethical concern about the nature of the relationship expressed in the disclosure. In effect, the moral pluralism and logics that have been seen to characterise accounting practice in general (e.g. Baud et al. 2019) could very well apply to the case of how social reporting (such as HRD) is approached by the organisation. At the same time, we refrain from recommending "mandatory" forms of HRD, since we do not believe there is a case that compliance with particular pre-determined standards of disclosure will adequately address the aspirations inherent to the ethical variant of stakeholder theory. Instead, we would suggest that HRD scholars and practitioners consider more explicitly the notion of the "ethics of care" (Gilligan 1982; Reiter 1996) and the principles (Reiter 1996, p. 39) of "individuals as interdependent," "relationships of attention and response," "care as strength," "importance of interpendence and interpersonal connections," and "needs of others as important.". In the context of the crucial relationship with employees, we would argue that the above could be important guiding principles for HR and HRD practices, which could complement-if not transcend-the largely individualistic-, contractual- and economic-led forms of corporate communication.

In terms of limitations, the current study includes a limited sample size, and there is the possibility of self-selection bias, since firms which did not disclose human resource expenditure (in order for us to calculate value added) were excluded from the sample. The findings may also be affected by additional firm-level factors such as political costs, thus warranting further research. Further studies with a larger sample size for a longer duration and a standardised HRD framework developed through computer aided content analyses technique and/or factor analysis may offer new insights that our current study has not been able to offer. Similarly, as with all archival studies of this nature, our measure and variables for HRD, governance, employee ideologies, and firm characteristics may or may not reflect practice. In-depth case studies may therefore offer insights about the processes underlying reporting and disclosure decisions, for example by conducting interviews of relevant actors e.g. employees, HR practitioners, managers, investors, labour unions, and governments.

Funding The study was not funded by any research Grants.

\section{Compliance with Ethical Standards}

Conflict of interest All author declares that they have no conflict of interest.

Ethical Approval This article does not contain any studies with human participants or animals performed by any of the authors.

Open Access This article is distributed under the terms of the Creative Commons Attribution 4.0 International License (http://creativeco mmons.org/licenses/by/4.0/), which permits unrestricted use, distribution, and reproduction in any medium, provided you give appropriate credit to the original author(s) and the source, provide a link to the Creative Commons license, and indicate if changes were made.

\section{Appendix}

See Table 10. 
Table 10 Variables and definitions/measurements

\begin{tabular}{|c|c|}
\hline Variable & Definition/measurement \\
\hline \multicolumn{2}{|l|}{ Firm characteristics } \\
\hline Firm size $(£ M n)$ & Natural logarithm of total market capitalisation \\
\hline Firm leverage & The ratio between total debt and total assets \\
\hline Firm profitability & Return on equity percentage \\
\hline Firm liquidity & Current asset ratio \\
\hline $\begin{array}{l}\text { Intellectual capital intensity (value } \\
\text { added per human capital) }\end{array}$ & Total value added to human resource expenditure ratio \\
\hline Employee productivity & Ratio between the net income before minority interest and the number of employees \\
\hline \multicolumn{2}{|l|}{ Corporate governance variables } \\
\hline Board size & Number of directors that sit on a board per year \\
\hline Audit committee size & Number of directors that sit on the audit committee per year \\
\hline Nomination committee size & Number of directors that sit on the nomination committee per year \\
\hline Remuneration committee size & Number of directors that sit on the remuneration committee per year \\
\hline Board independence & Number of non-executive directors to the total number of directors' ratio per year \\
\hline Audit committee meetings & Number of meetings of audit committee per year \\
\hline Remuneration committee meetings & Number of meetings of remuneration committee per year \\
\hline Nomination committee meetings & Number of meetings of nomination committee per year \\
\hline \multicolumn{2}{|l|}{ Employee relation ideology } \\
\hline Unitarist employee relation & $\begin{array}{l}\text { Firms' disposition towards employee relation ideology, measured as firms' disclosure on employee } \\
\text { relations and union activities ranging from } 0 \text { to } 5 \text {. The higher the score, the more unitarist the } \\
\text { employee relation ideology is }\end{array}$ \\
\hline \multicolumn{2}{|l|}{ Disclosure variables } \\
\hline Human resource disclosure & Overall HRD index ranging from 0 to 1 . The higher the score, the more substantive the disclosure is \\
\hline Procedural HRD & $\begin{array}{l}\text { Categorical procedural HRD index ranging from } 0 \text { to } 1 \text {. The higher the score, the more substantive the } \\
\text { disclosure is }\end{array}$ \\
\hline Sustainable HRD & $\begin{array}{l}\text { Categorical sustainable HRD index ranging from } 0 \text { to } 1 \text {. The higher the score, the more substantive the } \\
\text { disclosure is }\end{array}$ \\
\hline
\end{tabular}

The disclosure indices are calculated as the ratio between the summation of the actual disclosure scores for all the items considered under a particular index (22 items for HRD index, 10 items for procedural HRD index and 12 items for sustainable HRD index) and the summation of the ideal substantive disclosure for all the items considered under a particular index (i.e. $5 * 22$ for HRD index, $5 * 10$ for procedural HRD index and $5 * 12$ for sustainable HRD index). The value ranges from 0 to 1 . The higher the value of the index, the more substantive the HRD is

\section{References}

AAA. (1973). Report of the committee on human resource accounting. The Accounting Review (pp. 169-185). Sarasota: American Accounting Association.

Abeysekera, I. (2008). Motivations behind human capital disclosure in annual reports. Accounting Forum, 32(1), 16-29.

Abeysekera, I. (2010). The influence of board size on intellectual capital disclosure by Kenyan listed firms. Journal of Intellectual Capital, 11(4), 504-518.

Abeysekera, I., \& Guthrie, J. (2004). Human capital reporting in a developing nation. The British Accounting Review, 36(3), 251-268.

Abeysekera, I., \& Guthrie, J. (2005). An empirical investigation of annual reporting trends of intellectual capital in Sri Lanka. Critical Perspectives on Accounting, 16(3), 151-163.

Abhayawansa, S., \& Abeysekera, I. (2008). An explanation of human capital disclosure from the resource-based perspective. Journal of Human Resource Costing \& Accounting, 12(1), 51-64.

ACCA. (2009). Human capital management: An analysis of disclosure in UK reports. London: The Association of Chartered Certified Accountants.
Adams, C., \& Harte, G. (2000). Making discrimination visible: the potential for social accounting. Accounting Forum, 24(1), 56-79.

Amir, E., \& Lev, B. (1996). Value-relevance of nonfinancial information: The wireless communications industry. Journal of Accounting and Economics, 22(1-3), 3-30. https://doi.org/10.1016/S0165 -4101(96)00430-2.

An, Y., Davey, H., \& Eggleton, I. R. C. (2011). Towards a comprehensive theoretical framework for voluntary IC disclosure. Journal of Intellectual Capital, 12(4), 571-585. https://doi. org/10.1108/14691931111181733.

Armstrong, C. S., Guay, W. R., \& Weber, J. P. (2010). The role of information and financial reporting in corporate governance and debt contracting. Journal of Accounting and Economics, 50(2-3), 179-234.

Ashforth, B. E., \& Gibbs, B. W. (1990). The double-edge of organizational legitimation. Organization Science, 1(2), 177-194.

Ax, C., \& Marton, J. (2008). Human capital disclosures and management practices. Journal of Intellectual Capital, 9(3), 433-455.

Barako, D. G., Hancock, P., \& Izan, H. Y. (2006). Factors influencing voluntary corporate disclosure by Kenyan companies. Corporate Governance, 14(2), 107-125. 
Baud, C., Brivot, M., \& Himick, D. (2019). Accounting ethics and the fragmentation of value. Journal of Business Ethics. https://doi. org/10.1007/s10551-019-04186-9.

Beattie, V. (2005). Moving the financial accounting research front forward: the UK contribution. The British Accounting Review, $37(1), 85-114$.

Beattie, V., \& Smith, S. J. (2010). Human capital, value creation and disclosure. Journal of Human Resource Costing \& Accounting, 14(4), 262-285.

Bouten, L., Everaert, P., Van Liedekerke, L., De Moor, L., \& Christiaens, J. (2011). Corporate social responsibility reporting: A comprehensive picture? Accounting Forum, 35(3), 187-204.

Bowrin, A. R. (2018). Human resources disclosures by African and Caribbean companies. Journal of Accounting in Emerging Economies, 8(2), 244-278.

Brown, J. A. (2000). Competing ideologies in the accounting and industrial relations environment. The British Accounting Review, 32(1), 43-75.

Burchell, S., Clubb, C., \& Hopwood, A. G. (1985). Accounting in its social context: Towards a history of value added in the United Kingdom. Accounting, Organizations and Society, 10(4), 381-413.

Chartered Institute of Personnel Development, Invitation to tender for research. (2015). Retrieved September 08, 2015, from http:// www.cipd.co.uk/research/invitation-tender.aspx/.

Chartered Institute of Personnel Development, Invitation to tender for research. (2017). Retrieved September 22, 2018, from https ://www.cipd.co.uk/knowledge/strategy/analytics/human-capit al-analytics-report

Chen, J. C., \& Roberts, R. W. (2010). Toward a more coherent understanding of the organization-society relationship: A theoretical consideration for social and environmental accounting research. Journal of Business Ethics, 97(4), 651-665.

Clement, R. W. (2005). The lessons from stakeholder theory for US business leaders. Business Horizons, 48(3), 255-264.

Companies Act. (1985). Her Majesty's Stationery Office. London, UK.

Companies Act. (2006). Her Majesty's Stationery Office. London, UK.

Cormier, D., Aerts, W., Ledoux, M., \& Magnan, M. (2009). Attributes of social and human capital disclosure and information asymmetry between managers and investors. Canadian Journal of Administrative Sciences, 26(1), 71-88.

Cuganesan, S. (2006). Reporting organisational performance in managing human resources. Journal of Human Resource Costing \& Accounting, 10(3), 164-188.

Day, R., \& Woodward, T. (2004). Disclosure of information about employees in the Directors' report of UK published financial statements: substantive or symbolic? Accounting Forum, 28(1), $43-59$.

Donaldson, T., \& Preston, L. E. (1995). The stakeholder theory of the corporation: Concepts, evidence, and implications. Academy of Management Review, 20(1), 65-91.

DTI. (2003a). Accounting for people-consultation paper. London: Department of Trade and Industry.

DTI. (2003b). accounting for people-report of the taskforce on Human Capital Management. London: Department of Trade and Industry.

Ehnert, I., Parsa, S., Roper, I., Wagner, M., \& Muller-Camen, M. (2016). Reporting on sustainability and HRM: A comparative study of sustainability reporting practices by the world's largest companies. The International Journal of Human Resource Management, 27(1), 88-108.

Ejiogu, A. R., \& Ejiogu, C. (2018). Translation in the "contact zone" between accounting and human resource management: The nebulous idea of humans as assets and resources. Accounting, Auditing \& Accountability Journal, 31(7), 1932-1956.
Employment Act. (1982). Her Majesty's Stationery Office. London, UK.

Employment Protection Act. (1975). Her Majesty's Stationery Office. London, UK.

FRC. (2010). The UK Corporate Governance Code, London, Financial reporting council. Retrieved December 06, 2018, from https:// www.frc.org.uk/getattachment/31631a7a-bc5c-4e7b-bc3a-972b7 f17d5e2/UK-Corp-Gov-Code-June-2010.pdf.

FRC. (2012). The UK Corporate Governance Code, London, September. Financial Reporting Council.

Gilligan, C. (1982). In a different voice. Cambridge: Harvard University Press.

Guthrie, J., Petty, R., Yongvanich, K., \& Ricceri, F. (2004). Using content analysis as a research method to inquire into intellectual capital reporting. Journal of Intellectual Capital, 5(2), 282-293.

Hesketh, A. (2013). Valuing your talent: Resourceful assets? CIPD, London. https://www.cipd.co.uk/Images/valuing-your-talen t_2013-resourceful-assets_tcm18-9297.pdf. Accessed 6 Mar 2018.

Huang, C. C., Luther, R., Tayles, M., \& Haniffa, R. (2013). Human capital disclosures in developing countries: Figureheads and value creators. Journal of Applied Accounting Research, 14(2), $180-196$.

Jensen, M. C. (2002). Value maximization, stakeholder theory, and the corporate objective function. Business Ethics Quarterly, 12(2), 235-256.

Kadapakkam, P., Kumar, P. C., \& Riddick, L. A. (1998). The impact of cash flows and firm size on the investment: The international evidence. Journal of Banking \& Finance, 22(3), 293-320.

Lajili, K., \& Zéghal, D. (2005). Labor cost voluntary disclosures and firm equity values: Is human capital information value-relevant? Journal of International Accounting, Auditing and Taxation, 14(2), 121-138.

Lajili, K., \& Zéghal, D. (2006). Market performance impacts of human capital disclosures. Journal of Accounting and Public Policy, 25(2), 171-194.

Li, J., Mangena, M., \& Pike, R. (2012). The effect of audit committee characteristics on intellectual capital disclosure. The British Accounting Review, 44(2), 98-110.

Li, J., Pike, R., \& Haniffa, R. (2008). Intellectual capital disclosure and corporate governance structure in UK firms. Accounting and Business Research, 38(2), 137-159.

Lin, L., Huang, I., Du, P., \& Lin, T. (2012). Human capital disclosure and organizational performance: The moderating effects of knowledge intensity and organizational size. Management Decision, 50(10), 1790-1799.

Mahadeo, J. D., Oogarah-Hanuman, V., \& Soobaroyen, T. (2011). Changes in social and environmental reporting practices in an emerging economy (2004-2007): Exploring the relevance of stakeholder and legitimacy theories. Accounting Forum, 35(3), $158-175$.

Mäkelä, H. (2013). On the ideological role of employee reporting. Critical Perspectives on Accounting, 24(4), 360-378.

Marr, B., Schiuma, G., \& Neely, A. (2004). The dynamics of value creation: mapping your intellectual performance drivers. Journal of Intellectual Capital, 5(2), 312-325.

McCracken, M., McIvor, R., Treacy, R., \& Wall, T. (2018). A study of human capital reporting in the united Krigdom. Accounting Forum, 42, 130-141.

Michelon, G., Pilonato, S., \& Ricceri, F. (2015). CSR reporting practices and the quality of disclosure: An empirical analysis. Critical Perspectives on Accounting, 33, 59-78.

Mitchell, R. K., Agle, B. R., \& Wood, D. J. (1997). Toward a theory of stakeholder identification and salience: Defining the principle of who and what really counts. Academy of Management Review, 22(4), 853-886. 
Pedrini, M. (2007). Human capital convergences in intellectual capital and sustainability reports. Journal of Intellectual Capital, $8(2), 346-366$.

Popov, A. (2014). Credit constraints and investment in human capital: Training evidence from transition economies. Journal of Financial Intermediation, 23(1), 76-100. https://doi. org/10.1016/j.jfi.2013.11.003.

Reiter, S. A. (1996). The Kohlberg-Gilligan controversy: Lessons for accounting ethics education. Critical Perspectives on Accounting, 7(1), 33-54.

Roberts, R. W. (1992). Determinants of corporate social responsibility disclosure: An application of stakeholder theory. Accounting, Organizations and Society, 17(6), 595-612.

Roslender, R., \& Dyson, J. R. (1992). Accounting for the worth of employees: a new look at an old problem. British Accounting Review, 24, 311-329.

Roslender, R., Marks, A., \& Stevenson, J. (2015). Damned if you do, damned if you don't: Conflicting perspectives on the virtues of accounting for people. Critical Perspectives on Accounting, 27, 43-55.

Roslender, R., \& Stevenson, J. (2009). Accounting for people: A real step forward or more a case of wishing and hoping? Critical Perspectives on Accounting, 20(7), 855-869.

Roslender, R., Stevenson, J., \& Fincham, R. (2004). The UK human capital management initiative: A review of the accounting for people report. Journal of Human Resource Costing and Accounting, $8(1), 7-19$.

Samagaio, A., \& Rodrigues, R. (2016). Human capital and performance in young audit firms. Journal of Business Research, 69(11), 5354-5359.

Samudhram, A., Stewart, E., Wickramanayake, J., \& Sinnakkannu, J. (2014). Value relevance of human capital based disclosures: Moderating effects of labor productivity, investor sentiment, analyst coverage and audit quality. Advances in Accounting, 30(2), $338-353$
Sepasi, S., Braendle, U., \& Rahdari, A. H. (2018). Comprehensive sustainability reporting in higher education institutions. Social Responsibility Journal., 15, 155-170.

Smith, A. M. (1985). Employee Reporting in New Zealand. Doctoral dissertation, Victoria University of Wellington.

Soobaroyen, T., \& Ntim, C. G. (2013). Social and environmental accounting as symbolic and substantive means of legitimation: The case of HIV/AIDS reporting in South Africa. Accounting Forum, 37(2), 92-109.

Stittle, J. (2004). UK corporate reporting of human capital: A regulatory failure to evolve. Business and Society Review, 109(3), 311-337.

Su, H. Y. (2014). Business ethics and the development of intellectual capital. Journal of Business Ethics, 119(1), 87-98.

Subbarao, A. V., \& Zeghal, D. (1997). Human resources information disclosure in annual reports: An international comparison. Journal of Human Resource Costing \& Accounting, 2(2), 53-73.

Suchman, M. C. (1995). Managing legitimacy: Strategic and institutional approaches. Academy of Management Review, 20(3), 571-610.

Vithana, K., Jayasekera, R., Choudhry, T., \& Baruch, Y. (2018). HR as cost or investment: the distinction between short- vs. long-term focus of firm valuation. Academy of Management Proceedings, 2018, 10510.

Vuontisjärvi, T. (2006). Corporate social reporting in the European context and human resource disclosures: An analysis of Finnish companies. Journal of Business Ethics, 69(4), 331-354.

Wintermantel, R. E., \& Mattimore, K. L. (1997). In the changing world of human resources: Matching measures to mission. Human Resource Management, 36(3), 337.

Publisher's Note Springer Nature remains neutral with regard to jurisdictional claims in published maps and institutional affiliations. 